\title{
Schmidt hammer exposure-age dating of periglacial and glacial landforms in the Southern Swiss Alps based on $R$-value calibration using historical data
}

\author{
Cristian Scapozza $^{1}$, Chantal Del Siro ${ }^{2}$, Christophe Lambiel ${ }^{2}$, and Christian Ambrosi ${ }^{1}$ \\ ${ }^{1}$ Institute of Earth Sciences (IST), University of Applied Sciences and Arts of Southern Switzerland (SUPSI), \\ 6952 Canobbio, Switzerland \\ ${ }^{2}$ Institute of Earth Surface Dynamics (IDYST), University of Lausanne, \\ UNIL Mouline, 1015 Lausanne, Switzerland \\ Correspondence: Cristian Scapozza (cristian.scapozza@supsi.ch)
}

Received: 25 February 2021 - Revised: 1 September 2021 - Accepted: 7 October 2021 - Published: 15 November 2021

Abstract. As a contribution to the palaeoenvironmental history reconstruction of the Alpine periglacial domain, this study focuses on the Schmidt hammer exposure-age dating (SHD) of (peri-)glacial landforms using reboundvalue ( $R$-value) calibrations for 10 stations in the Scaradra glacier forefield (north-eastern part of the Ticino Canton, Lepontine Alps) and for 13 stations in the Splügenpass region (located between Switzerland and Italy, Rhaetian Alps). Linear calibration based on the known age of several moraines of the Scaradra glacier assessed by historical cartography allowed the reconstruction of the glacier fluctuations around the end of the Little Ice Age. Timing of deglaciation and of rock glacier development was defined in the Splügenpass region using the calibration of exposure ages based on two mule tracks built in $300 \mathrm{CE}$ and $1250 \mathrm{CE}$, respectively. Discussion on $R$-value analysis and calibration improves the knowledge on the potential use of SHD for numerical-age dating in Alpine geomorphological studies.

\section{Introduction}

Over the last decades, an increasing number of studies about the evolution of glacial and periglacial landforms during the Late Glacial and Holocene have been carried out, in order to better understand how high-mountain regions respond to climate change (e.g. Scapozza, 2016; Scotti et al., 2017; Lambiel, 2021; and references therein). As the Alpine periglacial domain is located almost exclusively above the upper limit of tall trees, it is rare to find remains of organic origin allowing numerical or absolute dating, such as radiocarbon or dendrochronology, to carry out absolute chronological correlations (e.g. Scapozza et al., 2010). The link between the geomorphic response to climate oscillations, highlighting in particular the reaction of the Alpine cryosphere to significant temperature warming phases, was deepened in particular due to the improvement of numerical exposure-age dating techniques, such as cosmogenic nuclide dating and Schmidt hammer exposure-age dating (SHD) (e.g. Scotti et al., 2017; Win- kler and Lambiel, 2018; Steinemann et al., 2020). As a consequence, the number of dates on Alpine glacial, periglacial, and paraglacial landforms available today has greatly increased. This is also the case for the Southern Swiss Alps, where studies related to the landscape evolution after the Last Glacial Maximum have increased in the last decade with the revision of already published radiocarbon and cosmogenic nuclide dates, new cosmogenic nuclide dating, and the large number of exposure ages derived from Schmidt hammer rebound values (e.g. Scapozza, 2016; Kamleitner et al., 2020; Scapozza and Ambrosi, 2021).

In order to contribute to the reconstruction of the palaeoenvironmental history of the Alpine periglacial domain, this research has focused on the morphostratigraphy of Late Holocene glacial deposits of the upper part of the Scaradra Valley (north-eastern part of the Ticino Canton, Lepontine Alps, Fig. 1a) and of Late Glacial and Holocene periglacial and glacial landforms of the Splügenpass region (transnational pass between Switzerland and Italy, Rhaetian Alps, 


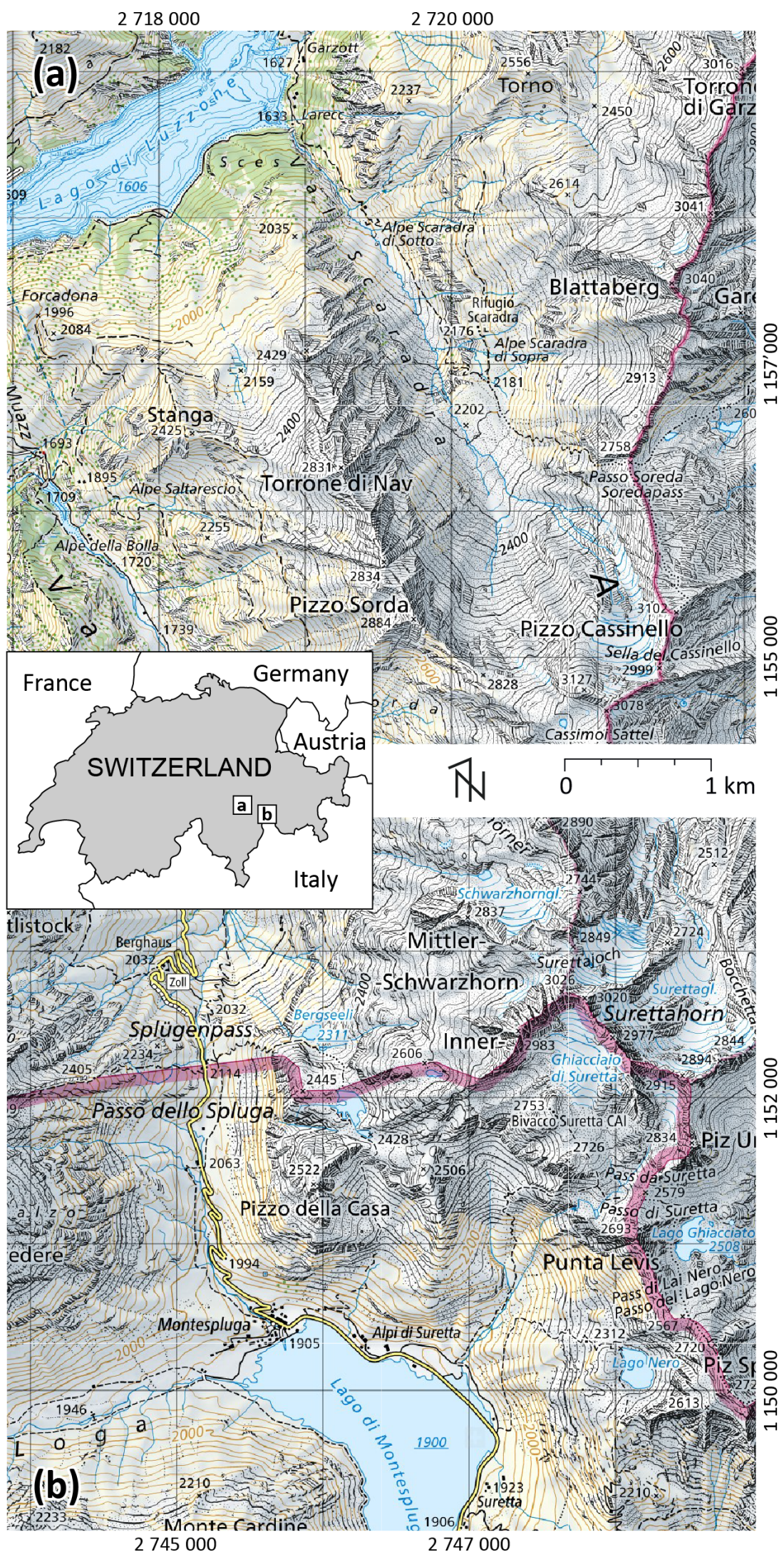

Figure 1. Location of Scaradra Valley (a) and Splügenpass area (b). Coordinates CH1903+/LV95. Base map: Swiss National Map 1 : 50000 , 2016, (C) Swiss Federal Office of Topography swisstopo. 
Fig. 1b). These investigations also aim to improve the knowledge on the potential use of SHD for numerical-age dating in Alpine geomorphological studies, a field of research that is currently rapidly developing and that can be complementary, or even alternative, to cosmogenic nuclide and/or optically stimulated luminescence dating in the understanding of complex glacial-periglacial-paraglacial land systems.

Within this framework, the four objectives are therefore of two types. By using SHD, this study aims to define (1) the age of the glacial deposits around the end of the Little Ice Age (LIA) of the Scaradra glacier and of the moraines of supposed Early and Mid-Holocene age in the Splügenpass region and (2) the development phases of the Splügenpass relict rock glacier, which has the special feature of being crossed by two historical mule tracks. Furthermore, it aims to improve the use of the Schmidt hammer for dating surfaces by (3) defining local calibration curves of Schmidt hammer rebound values based on historical surfaces of known age and (4) discussing different sampling strategies and analysing methods of Schmidt hammer $R$ values on the basis of the chronological extent of the surfaces dated in the two case studies and of the historical information used in the exposure-age calibration.

\section{Schmidt hammer exposure-age dating (SHD)}

Surface exposure-age dating was conducted using the analysis of Schmidt hammer rebound values ( $R$ values). The Schmidt hammer, also called concrete sclerometer, is a portable mechanical device allowing the quick and nondestructive inspection of the quality of a material, such as concrete, bedrock, or boulder surfaces, based on the measurement of an $R$ value (Schmidt, 1950). The $a$-dimensional $R$ value is proportional to the compressive strength of the rock surface which, for a given lithology subject to similar climate conditions, can be considered proportional to the weathering degree of the rock surface (McCarroll, 1989; Goudie, 2006). Considering the rock transport history, which may influence the surface roughness of the measured sample, it is possible to determine a relative exposure age of the rock surface on the basis of measured $R$ values. High values indicate young ages, and vice versa. The interpretation of $R$ values in terms of relative exposure age is therefore very simple: a rock surface presenting an $R$ value lower than another is exposed to weathering over a longer time period. In general, but also for a same lithology, the surface roughness of a rock clast can have a significant influence on the measured $R$ values. This is particularly the case in glacial, fluvioglacial, and fluvial environments, where the clasts can be more or less polished and rounded off depending on their transport path and mechanisms (e.g. on, under, or inside a glacier), distance, or turbulence (e.g. McCarroll, 1989; Shakesby et al., 2006).

The measurements carried out in this study were made by choosing the widest variety of measuring stations per site
(Scapozza et al., 2014b; Scapozza, 2015). On moraine ridges, $R$ values were measured on boulders as close as possible to the ridge, in order to date the surface layer of the moraine and to minimise the effect of a possible boulder reworking by gravitational or torrential processes. On rock glaciers and talus slopes, several stations were measured along a central line, in order to cover the whole landform from the distal (the frontal ridge for a rock glacier) to the roots (Fig. 2a). On rock glaciers, the measurement stations were aligned along the central flow line. $R$ values were also measured on recent rockfall deposits to determine the maximal rebound value for a given lithology.

For each measurement station, at least five boulders were measured (Fig. 2b). For each boulder, $R$ values were measured at the same location four times (four consecutive impacts) and this for at least 10 readings for every boulder (Fig. 2c). Only the two median values (impacts 2 and 3) for each reading of four impacts were taken into account (Scapozza et al., 2014a; Scapozza, 2015). The first impact was never used because it systematically gave a lower $R$ value than impacts 2,3 , and 4 , probably due to dust, microlichens and other impurities covering the rock surface and perturbing the measurement (Scapozza, 2013). The fourth impact was used as a control value for impacts 2 and 3 and generally presented the highest $R$ value because of the thinning of the weathering surface layer caused by impacts 1 to 3 .

The mean $R$ value derived from impacts 2 and 3 for a single measurement station was calculated using the arithmetic mean of the 50 series of measurements (10 readings on five boulders) and was plotted with the $95 \%$ confidence interval, which represents the standard error of measurement (Kellerer-Pirklbauer, 2008).

The $95 \%$ confidence interval is a fundamental parameter for the comparison of determined relative exposure ages. The exposure age between two measurements is significantly different only if their $95 \%$ confidence intervals do not overlap (Winkler, 2000). In the case of $R$ values determined on two or more rock surfaces of known age, an age calibration is possible by linear regression, as proposed, for example, by Shakesby et al. (2006, 2011), Kellerer-Pirklbauer (2008), Matthews and Owen (2010), Matthews and Winkler (2011), Scapozza et al. (2014a), Scapozza (2015), and Winkler and Lambiel (2018). The error range of the calibrated Schmidt hammer exposure ages was calculated by combining the sampling error of the measured $R$ values (expressed by the $95 \%$ confidence interval) and the error of the calibration curve determined from its slope and from the error associated with the fixed points used for the calibration. Calibrated exposure ages are presented in years (yr) or millennia (kyr) before 2000 (noted as "b2k"). For recent times, dates are also presented with the notation $\mathrm{CE}$ (common era) or $\mathrm{BCE}$ (before the common era), which is an international standard and an alternative to the equivalent of $\mathrm{BC}$ (before Christ) and AD (Anno Domini) notation. 


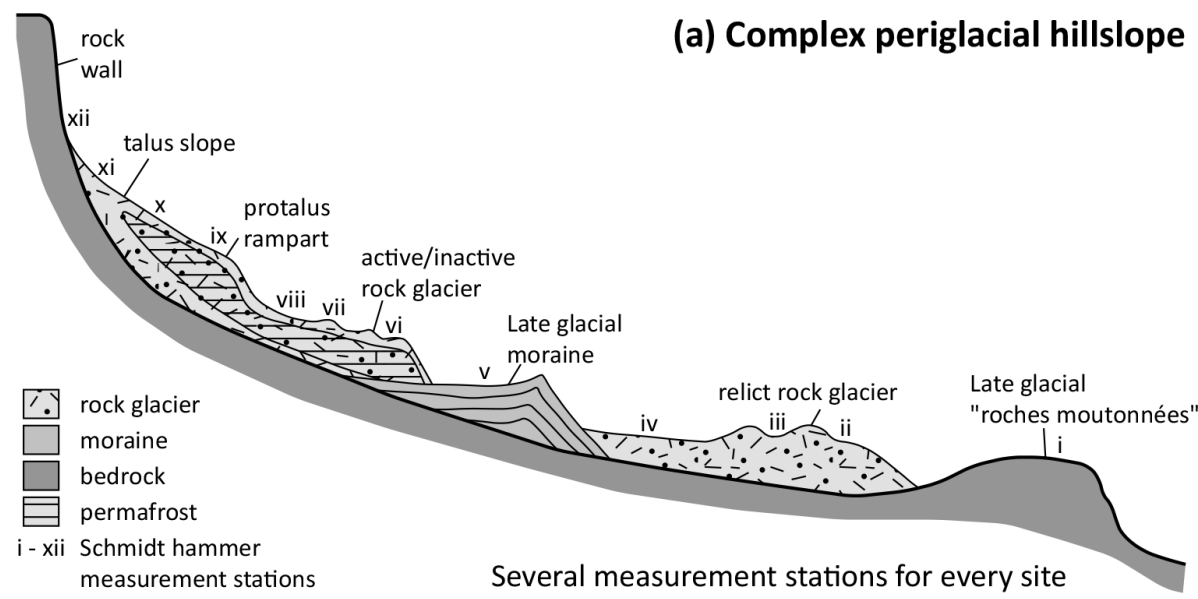

\section{(b) Example of the station vi}

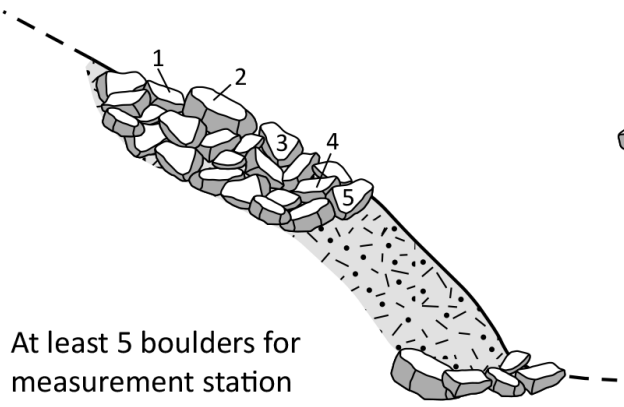

(c) Example of the boulders 1 to 3

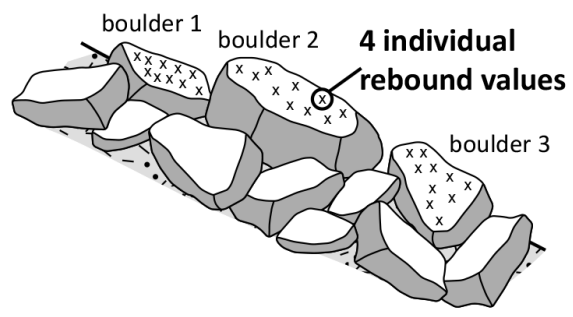

At least 10 readings for every boulder

Figure 2. Sampling strategy for SHD (modified from Scapozza, 2013).

The measurements for this study were carried out with a digital Schmidt hammer (model SilverSchmidt), type N (impact energy of $2.207 \mathrm{Nm}$ ), produced by the Swiss company Proceq.

\section{Case study 1: historical evolution of the Vadrecc di Scaradra}

\subsection{Geographical and historical framework}

The Val Scaradra (Scaradra Valley) is a SSE-NNW-oriented side valley of the Blenio District (Fig. 1a), which is located in the north-eastern part of the Ticino Canton (Adula Alps, which are part of the Lepontine Alps). The highest point is the Cima di Aquila (3127 m a.s.l.), whereas the lowest point is located at an altitude of $1606 \mathrm{~m}$ a.s.l. close to Larecc, where the Ri di Scaradra (Scaradra stream) flows into the Lago di Luzzone (Luzzone Lake). Tall trees are present only in the lower part of Scaradra Valley. The timberline (the limit of closed forests) reaches a maximum altitude of $1960 \mathrm{~m}$ a.s.l., whereas the treeline (the limit of tree growth) is located at about $2120 \mathrm{~m}$ a.s.l. These two ecological limits were perturbed in the past by cattle and sheep grazing, for which the alpine huts of Scaradra di Sotto (1805 m a.s.l.) and Scaradra di Sopra (2176 m a.s.l.) were built.
The bedrock of the upper part of Scaradra Valley is composed by orthogneiss (Zervreila orthogneiss and Garenstock augengneiss), by paragneiss and mica schists of the Salahorn formation, and by lenses of dolomitic marble and quartzite of the undifferentiated Mesozoic cover (Cavargna-Sani et al., 2014). All these lithologies belong to the Adula nappe (Lower Penninic).

Two north-oriented glaciers are present in the higher part of Scaradra Valley: the Vadrecc di Sorda (Sorda glacier, C43/04 according to the code adopted in Maisch, 1992) and the Vadrecc di Scaradra (Scaradra glacier, C43/06), which formed a single glacier in the 19th and early 20th centuries, before separating between 1907 and $1922 \mathrm{CE}$. In $1850 \mathrm{CE}$ the glacier front altitude was $2180 \mathrm{~m}$ a.s.l., whereas the calculated equilibrium line altitude (ELA) based on an accumulation area ratio (AAR) of 0.67 was $2590 \mathrm{~m}$ a.s.l. for the Sorda glacier and $2450 \mathrm{~m}$ a.s.l. for the Scaradra glacier (Maisch, 1992; Scapozza and Scapozza, 2015).

The historical positions of the Scaradra glaciers were reconstructed through the analysis of historical sources (Scapozza, 2014) and the georeferencing of historical topographic maps (Del Siro, 2019) from 1854 to 2016 CE. Four different map sources are available at a scale of 1:50000 or larger: (1) the original relief for the Dufour Map (Topo- 

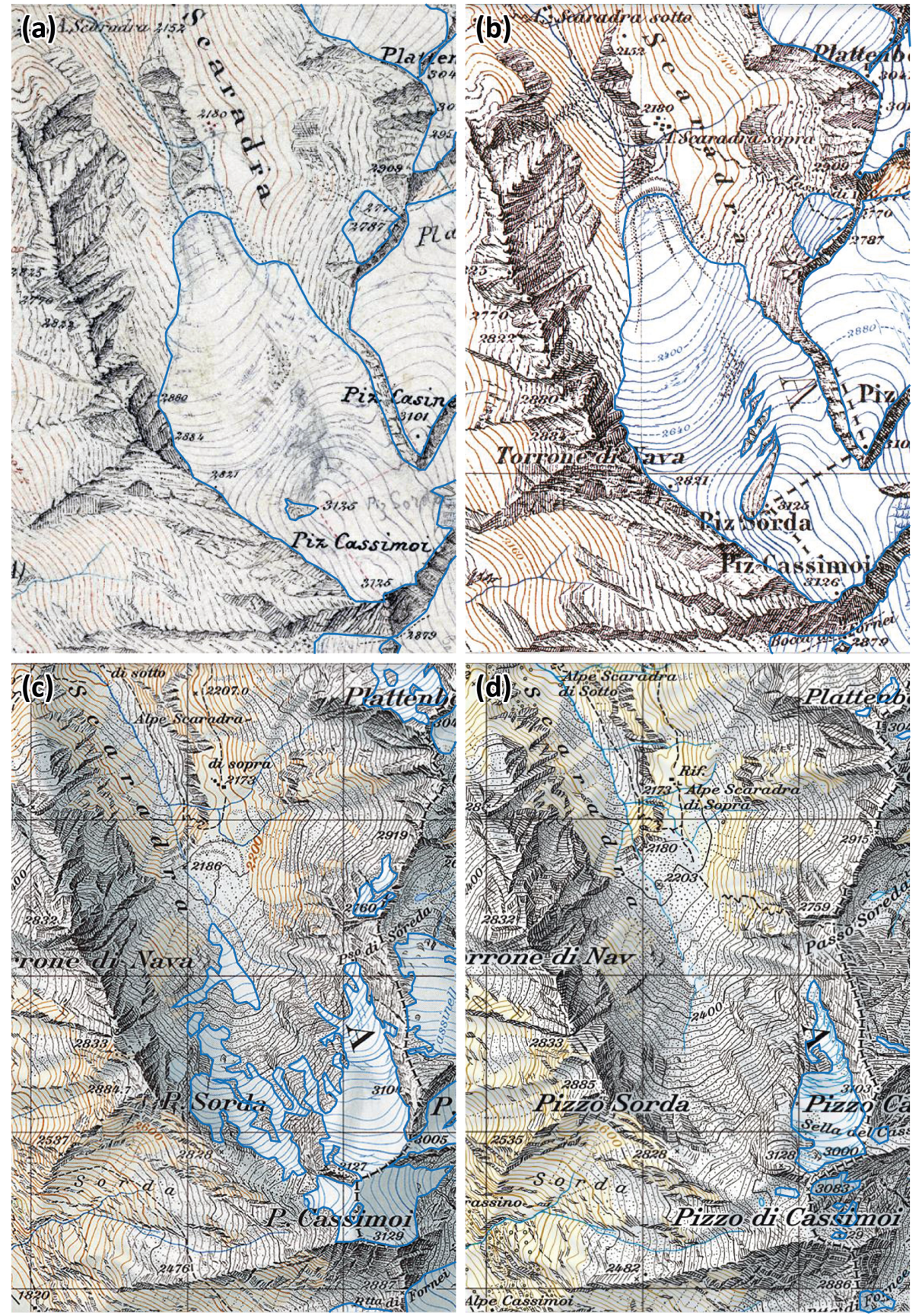

Figure 3. The retreat of the glaciers (outline in blue) through historical topographic maps of the Scaradra Valley for (a) 1854, (b) 1872, (c) 1966, and (d) 2016 CE. Details on the atlas edition in the text. (C) Swiss Federal Office of Topography swisstopo.

graphical Map of Switzerland, sheet OA 443, Feuille XIX. Sect. 2, 1:50000) cartographed by Hermann Siegfried in 1854CE (Fig. 3a); (2) the 1872, 1881, 1907, 1922, 1928, and 1935 CE editions of the Sheet 504/Olivone of the Siegfried Map (Topographical Atlas of Switzerland, $1: 50000$; Fig. 3b); (3) the 1950, 1954, and $1961 \mathrm{CE}$ editions of the Sheet 266/Valle Leventina (National Map of Switzerland 1:50000); and (4) the 1966, 1970, 1977, 1983,
1989, 1995, 2001, 2006, 2012, and 2016 CE editions of the Sheet 1253/Olivone (National Map of Switzerland 1: 25000; Fig. $3 \mathrm{c}$ and d). According to the original relief for the Dufour Map of $1854 \mathrm{CE}$ and to the historical reconstructions carried out in the Adula Alps, the more external historical moraine ridge, deposited during the maximal glacier advance of the third cold phase of the Little Ice Age (LIA), could be dated between 1817 and 1820 CE (Scapozza, 2014, 2019a). 


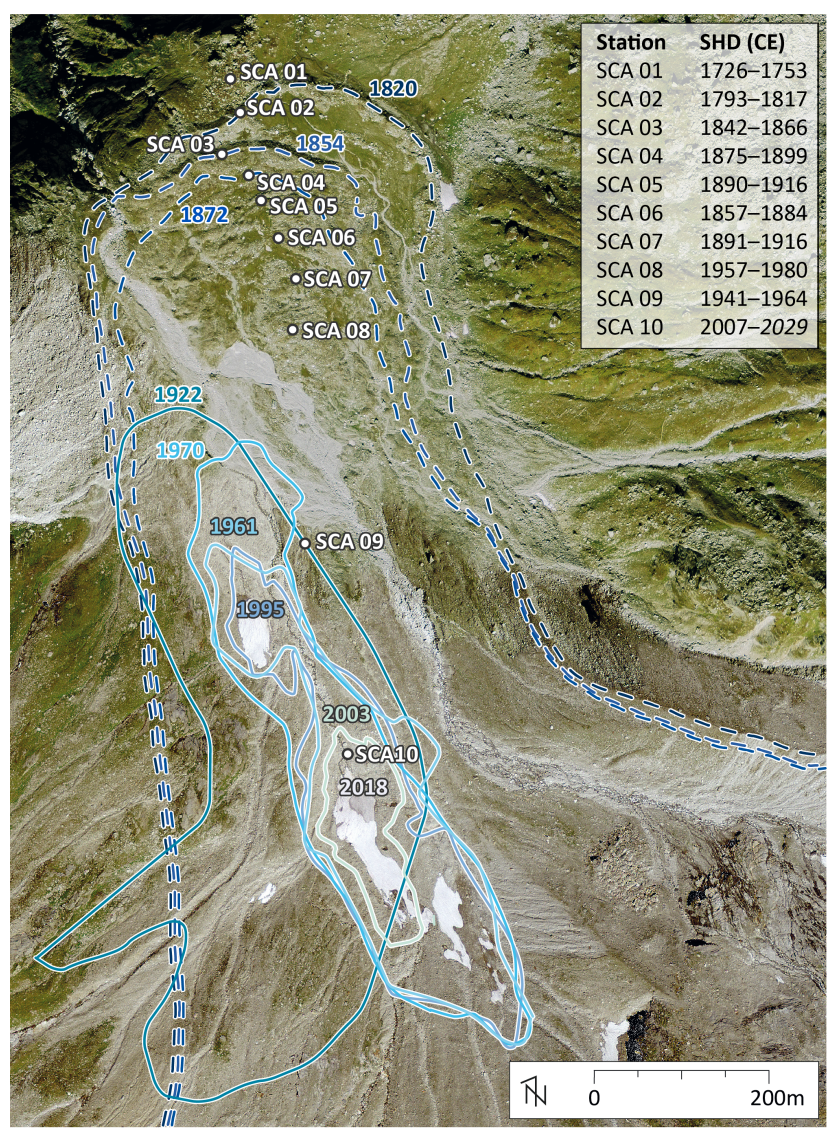

Figure 4. Evolution of the Scaradra glacier surface reconstructed using the historical maps and SHD measurement stations. Age calibrations were performed using measurement stations SCA 03 (1854 CE) and SCA 10 (2018 CE). Orthophoto of 2018: (C) Swiss Federal Office of Topography swisstopo.

\subsection{SHD dating}

\subsubsection{R-value measurements}

The $R$-value measurements of 10 stations were performed on 22 October 2018 in the proglacial area of the Scaradra glacier (Fig. 4 and Table 1), from a small moraine ridge located outside the 1817-1820 CE position (station SCA 01) to the boulders located just downslope of the glacier portal (SCA 10). All the measurements were carried out on boulders composed by paragneisses of the Salahorn formation.

The minimum $R$ value of $53 \pm 0.82$ (SCA 01) was measured on the lichen-covered moraine ridge located outside the moraine ridge attributed to the maximal LIA advance of 1817-1820 CE, whereas the maximum $R$ value of $70 \pm 0.69$ (SCA 10) was measured just downslope of the glacier portal, on boulders deglaciated in summer $2018 \mathrm{CE}$. The $95 \%$ confidence intervals are comprised between 0.68 and 0.82 , with the lowest values corresponding to the station with the highest $R$ value (SCA 09 and SCA 10), and vice versa (SCA 01).
Considering the $95 \%$ confidence intervals, the external moraine ridge SCA 01 is significantly older than SCA 02, which is in turn significantly older than the post- 1850 moraine ridges. The LIA moraine ridge corresponding with the 1850-1854 CE advance represented in the original relief for the Dufour Map drawn in 1854 is significantly older than post-LIA moraine ridges, built between 1872 and $1922 \mathrm{CE}$ (measuring stations SCA 04 to SCA 08), according to the first four editions of the Siegfried Map. The only exception is constituted by station SCA 06, which does not present a significant age difference compared to SCA 03 and SCA 04. For the 20th and 21st century stations, even though they are located further upslope in the proglacial area, SCA 09 is not significantly younger than SCA 08, while it is significantly older than SCA 10 . SCA 10 clearly and unambiguously constitutes the youngest surface of the entire Scaradra glacier proglacial area.

\subsubsection{Exposure-age calibration}

Schmidt hammer exposure-age calibration by linear regression was performed using measurement stations SCA 03 and SCA 10, attributed respectively to 1854 and $2018 \mathrm{CE}$ (Table 2 ). The resulting relationship between $R$ value and exposure age $(\mathrm{yr} b 2 \mathrm{k})$ is

$R=\mathrm{yr} \cdot(-0.061)+68.902 \Leftrightarrow \mathrm{yr}=\frac{R-68.902}{-0.061}$.

The moraine ridge, on which SHD SCA 01 was performed, was considered Early Holocene based on its morphology and lichen cover. It turned out to be from the middle of the 18 th century. The well-developed external moraine ridge predating $1854 \mathrm{CE}$ (it is clearly detached from the glacier front drawn in $1854 \mathrm{CE}$ in the original relief for the Dufour Map; see Fig. 3a) and on which was executed SHD SCA 02 was deposited between the end of the 18th and the beginning of the 19th centuries. This result is very consistent with the reconstructions of glacier fluctuations in the Adula Alps during the last phase of the LIA, which indicates a glacier progression starting in 1760, increasing after 1790, and culminating in the 1817-1820 CE period (Scapozza, 2014, 2019a). SHD SCA 03 was measured on the mid-19th century moraine ridge, the one where the glacier front position is $1854 \mathrm{CE}$. It was dated between 1842 and $1866 \mathrm{CE}$. The moraine ridges where SHD SCA 04 to SCA 07 were performed gave dates between 1875 (minimum age of SCA 04) and 1916 CE (maximum age of SCA 07), which is perfectly coherent with the historical behaviour of the Scaradra glacier: according to the Siegfried Maps, the glacier reached the position of the measuring station SCA 04 in $1872 \mathrm{CE}$ and retreated upslope of SCA 07 in 1922 CE (Fig. 4). For recent times, the date comprised between 1941 and 1964 CE for SHD SCA 09 is also very consistent with historical mapping, considering that this emplacement was deglaciated between 1922 and 1961/70 CE. Finally, SHD SCA 10 is also coherent with a 
Table 1. Schmidt hammer measurements performed on the Scaradra glacier proglacial area. LIA: 1350-1860 CE according to Zumbühl and Holzhauser (1998).

\begin{tabular}{|c|c|c|c|c|c|c|c|}
\hline \multirow[t]{2}{*}{ Station } & \multicolumn{3}{|c|}{ Coordinates CH1903+/LV 95} & \multicolumn{3}{|c|}{$R$ value } & \multirow[t]{2}{*}{ Remarks } \\
\hline & East & North & $\begin{array}{l}\text { Altitude } \\
\text { (ma.s.1.) }\end{array}$ & Mean & $\begin{array}{r}\text { Standard } \\
\text { deviation }\end{array}$ & $\begin{array}{c}95 \% \\
\text { confidence } \\
\text { interval }\end{array}$ & \\
\hline SCA 01 & 2720125 & 1156890 & 2181 & 53 & 9 & \pm 0.82 & $\begin{array}{l}\text { Early Holocene (?) moraine } \\
\text { ridge covered by lichens }\end{array}$ \\
\hline SCA 02 & 2720135 & 1156850 & 2185 & 57 & 11 & \pm 0.73 & $\begin{array}{l}\text { External LIA moraine ridge } \\
(1817-1820 ? \mathrm{CE})\end{array}$ \\
\hline SCA 03 & 2720120 & 1156800 & 2191 & 60 & 7 & \pm 0.71 & LIA moraine ridge (1854 CE) \\
\hline SCA 04 & 2720145 & 1156775 & 2192 & 62 & 7 & \pm 0.72 & LIA moraine ridge \\
\hline SCA 05 & 2720160 & 1156750 & 2194 & 63 & 4 & \pm 0.79 & Post-LIA moraine ridge \\
\hline SCA 06 & 2720180 & 1156705 & 2196 & 61 & 6 & \pm 0.81 & Post-LIA moraine ridge \\
\hline SCA 07 & 2720200 & 1156660 & 2198 & 63 & 6 & \pm 0.75 & Post-LIA moraine ridge \\
\hline SCA 08 & 2720195 & 1156600 & 2203 & 67 & 4 & \pm 0.71 & Post-LIA moraine ridge \\
\hline SCA 09 & 2720210 & 1156355 & 2216 & 66 & 6 & \pm 0.68 & 20 th century moraine ridge \\
\hline SCA 10 & 2720260 & 1156115 & 2260 & 70 & 5 & \pm 0.69 & $\begin{array}{l}\text { Recently (2018 CE) } \\
\text { deglaciated area }\end{array}$ \\
\hline
\end{tabular}

Table 2. Schmidt hammer exposure-age dating (SHD) on the Scaradra glacier proglacial area. The age-error calculation was based on the $95 \%$ confidence interval. In italics, aberrant values are shown projected into the future.

\begin{tabular}{|c|c|c|c|c|c|c|}
\hline \multirow[t]{2}{*}{ Station } & \multicolumn{2}{|c|}{$R$ value } & \multicolumn{4}{|c|}{ Chronology } \\
\hline & Mean & $\begin{array}{c}95 \% \\
\text { confidence } \\
\text { interval }\end{array}$ & $\begin{array}{r}\text { Attributed } \\
\text { age }(\mathrm{yr} \text { b2k) }\end{array}$ & $\begin{array}{r}\text { Calculated } \\
\text { mean age } \\
(\mathrm{yr} \text { b2k) }\end{array}$ & $\begin{array}{l}\text { Age } \\
\text { error } \\
( \pm y r)\end{array}$ & $\begin{array}{c}\text { Calculated } \\
\text { age (CE) }\end{array}$ \\
\hline SCA 01 & 53 & \pm 0.82 & - & 261 & 13 & $1726-1753$ \\
\hline SCA 02 & 57 & \pm 0.73 & - & 195 & 12 & 1793-1817 \\
\hline SCA 03 & 60 & \pm 0.71 & 146 & 146 & 12 & 1842-1866 \\
\hline SCA 04 & 62 & \pm 0.72 & - & 113 & 12 & 1875-1899 \\
\hline SCA 05 & 63 & \pm 0.79 & - & 97 & 13 & 1890-1916 \\
\hline SCA 06 & 61 & \pm 0.81 & - & 130 & 13 & 1857-1884 \\
\hline SCA 07 & 63 & \pm 0.75 & - & 97 & 12 & 1891-1916 \\
\hline SCA 08 & 67 & \pm 0.71 & - & 31 & 12 & 1957-1980 \\
\hline SCA 09 & 66 & \pm 0.68 & - & 48 & 11 & 1941-1964 \\
\hline SCA 10 & 70 & \pm 0.69 & -18 & -18 & 11 & 2007-2029 \\
\hline
\end{tabular}

recent deglaciation (i.e. after $2003 \mathrm{CE}$ ) of the area located just downslope of the glacier portal.

The only exception is constituted by SHD SCA 08, which is not coherent with the glacier retreat in this area considering that the measuring station has been ice-free at least since 1922 CE. As SCA 08 is relatively close to the fluvioglacial deposits coming from the Vadrecc di Sorda after 1922 CE (see Figs. 3c, d and 4), it can be assumed that a debris supply occurred by fluvial or torrential processes in the second half of the 20th century as indicated by SHD SCA 08 .
4 Case study 2: glaciers and rock glaciers of the Splügenpass region

\subsection{Geographical and historical framework}

Culminating at $2114 \mathrm{~m}$ a.s.l., the Splügenpass (Passo dello Spluga in Italian) is a transnational Alpine pass connecting the Rheinwald valley (Graubünden Canton, Switzerland) to the north with the Spluga/San Giacomo Valley (Valle Spluga/Val San Giacomo in Italian, province of Sondrio, 
Lombardy, Italy) to the south (Fig. 1b). The Splügenpass is at the limit between the Adula Alps (part of the Lepontine Alps) to the west (the highest point dominating the pass is Pizzo Tambò, 3279 ma.s.l.) and the Alpi del Platta (part of the Western Rhaetian Alps) to the east (with the Punta Nera, or Pizzo Suretta/Surettahorn, $3027 \mathrm{~m}$ a.s.l., as the highest point directly close to the pass). Tall trees are present only below $2020 \mathrm{~m}$ a.s.l. (altitude of the treeline). The timberline reaches $1970 \mathrm{~m}$ a.s.l. north of the Splügenpass and $1880 \mathrm{~m}$ a.s.l. to the south. As for many Alpine valleys, the upper limit of tall trees in this region is perturbed by pastoral activity and human settlements, such as Berghaus (2032 ma.s.l.) to the north and Montespluga and Alpi di Suretta (1905 m a.s.l.) to the south.

The bedrock composition is dominated by biotite schist and orthogneiss of the Tambo nappe west of the Splügenpass and by metagranite porphyr (Rofna-Porphyr) of the Suretta nappe east of the Splügenpass (swisstopo, 2020). Close to the Splügenpass, the bedrock is composed, from west to east, by paragneisses and calc schists of the Knorren melange (Obrist group), dolomites and cellular dolomites of the Kalkberg group, and calcareous and siliceous marble of the Tumpriv group (swisstopo, 2020). The Obrist and Tumpriv groups belong to the Gelbhorn nappe, while the Kalkberg group belongs to the Tschera-Kalkberg nappe; these two nappes, as well as the Tambo and Suretta nappes, are part of the Middle Penninic.

In the area where Schmidt hammer measurements were performed, two glaciers are present: the Surettahorn-W (A13J/03 according to the code adopted in Maisch, 1992) in Graubünden on the western side of Punta Nera and the Ghiacciaio di Suretta (Suretta glacier, ITA01/01) in province of Sondrio on the southern side of Punta Nera. The front altitude in $1850 \mathrm{CE}$ was $2325 \mathrm{~m}$ a.s.l. for A13J/03 and $2450 \mathrm{~m}$ a.s.l. for ITA01/01, whereas the ELA based on an AAR of 0.67 was 2660 and $2675 \mathrm{~m}$ a.s.l., respectively (Maisch, 1992).

The Splügenpass has been in use since the Iron age, as evidenced by the discovery of an iron ingot in the immediate vicinity of the summit (Simonett, 2013). Several paths, mule tracks, and roads have been built since the Roman period (IVS Dokumentation Kanton Graubünden, 1992a). In this study, we have investigated in particular the two mule tracks crossing a relict rock glacier located just south of the Splügenpass (Fig. 5). The two mule tracks are about $3 \mathrm{~m}$ wide and were built with large pebbles and boulders. The lower mule track was probably built during the Roman period, as the Splügenpass was mentioned in the Itinerarium Antonini of around $300 \mathrm{CE}$ and is reported in the Peutingerian Table of the third century CE (Simonett, 2013). The higher mule track was built between the High and Late Middle Ages during the 13th century, as a consequence of the degradation of the older one, probably after 1226 and before 1300 CE (IVS Dokumentation Kanton Graubünden, 1992a, b; Simonett, 2013). According to historians, the new upper mule track was built because the lower mule track seems to have been partially

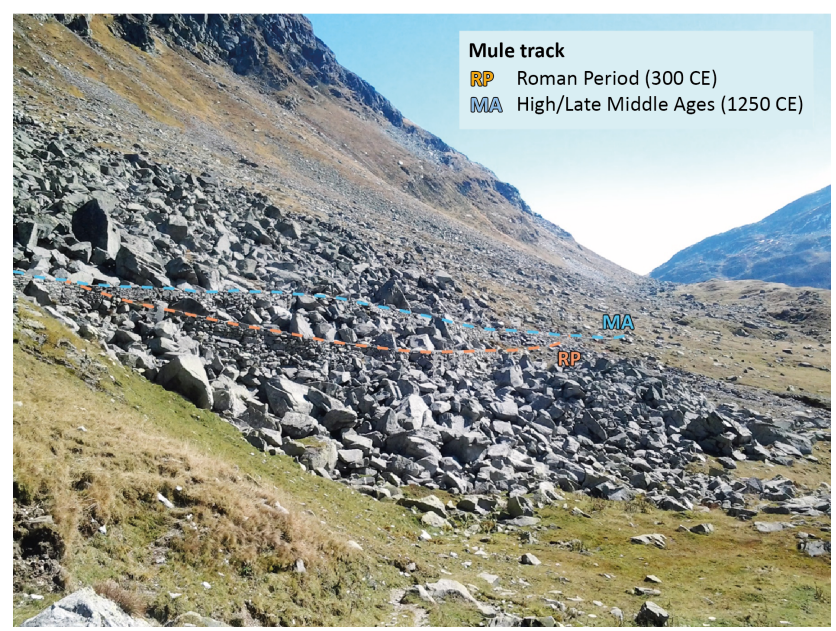

Figure 5. The Splügenpass rock glacier with the two historical mule tracks crossing its frontal part. The arched shape of the RP mule track is probably related to permafrost creep between 300 and $1250 \mathrm{CE}$ (photo: Cristian Scapozza).

buried by falling boulders at some locations (IVS Dokumentation Kanton Graubünden, 1992b). The arched shape of the Roman period mule track (Fig. 5) seems to indicate a movement of this part of the rock glacier. On the other hand, the straight direction of the Middle Age mule track would indicate that the movement of the rock glacier stopped before its building. An alternative age attribution of the two mule tracks was proposed by Merisio (2014), who claims the lower one was built in $1643 \mathrm{CE}$ and the upper one in $1716 \mathrm{CE}$.

\subsection{SHD dating \\ 4.2.1 $R$-value measurements}

$R$ values were calculated for 13 measurement stations located close to the Splügenpass (in both Switzerland and Italy) and on the valley downslope of the Suretta glacier (Ghiacciaio di Suretta, Italy) (Fig. 6 and Table 3). All the stations were measured on metagranite porphyr of the Suretta-Nappe (Rofna-Porphyr). In the area of the Splügenpass, the measurements are concentrated on the relict rock glacier crossed by the two historical mule tracks, from the front to the rooting zone (measurement stations SPL 01 to SPL 08), on the roches moutonnées located just north-east of the pass (SPL 09) and on the moraine ridge damming the Bergseeli lake (SPL 10) considered to possibly date from the Early Holocene on the basis of its position, lichen cover, and morphology. The roches moutonnées at the Splügenpass (SPL 09) were icefree from $16.25 \mathrm{kyr} b 2 \mathrm{k}$, which corresponds to the maximum age of deglaciation of the San Bernardino Pass located at $12 \mathrm{~km}$ to the west with respect to the Splügenpass. This age is derived from the radiocarbon date B-874 (Table 5) of gyttja, a mud formed from the partial decay of peat in a peat bog formed after the glacier retreat (Scapozza et al., 2014b). 


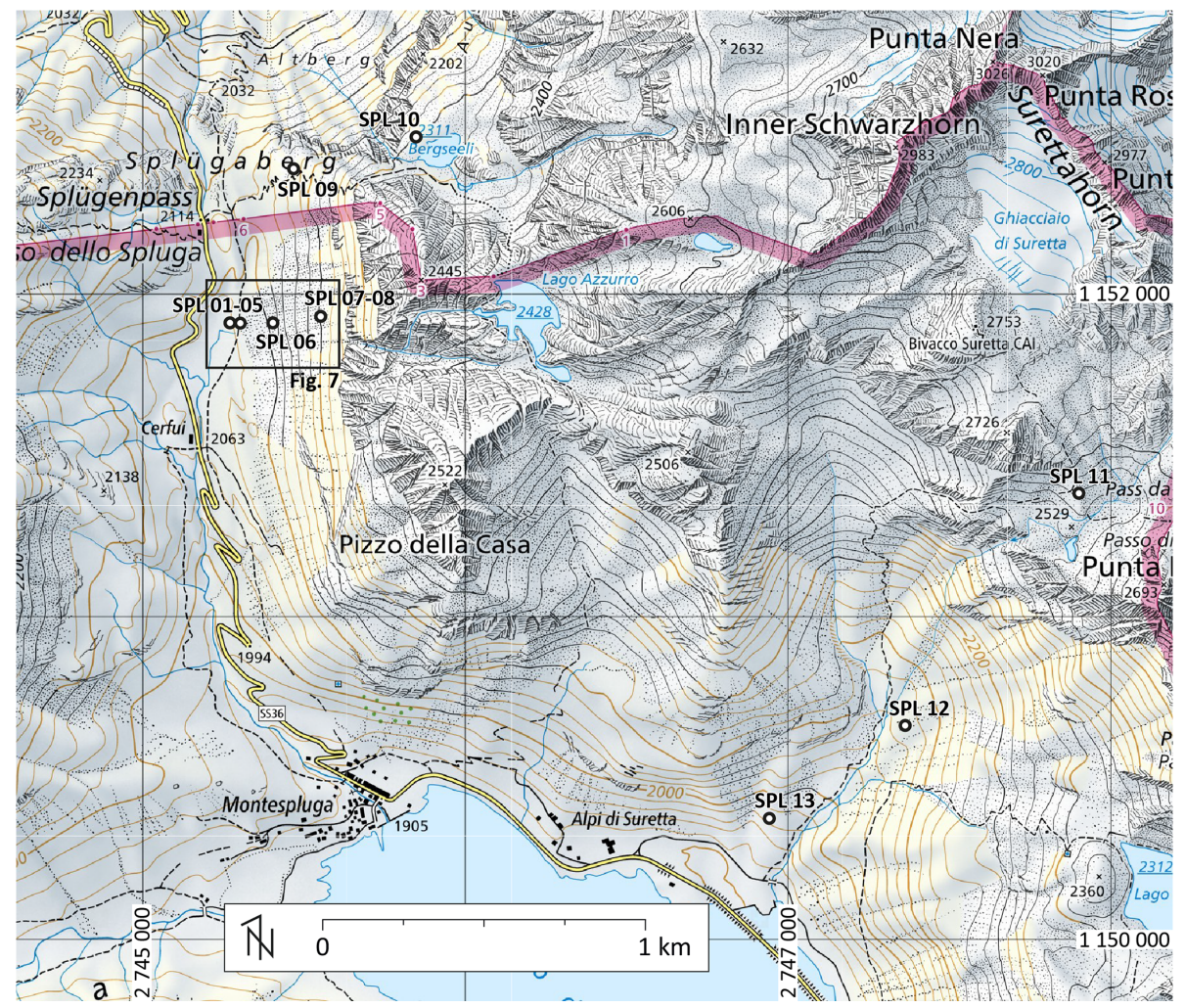

Figure 6. SHD measurement stations in the Splügenpass region. Coordinates CH1903+/LV95. Base map: Swiss National Map 1 : 50000, 2015, (C) Swiss Federal Office of Topography swisstopo.

SPL 11 was measured on the external Late Holocene moraine ridge of the Suretta glacier, while SPL 12 and SPL 13 were measured on moraine ridges located about $1 \mathrm{~km}$ downslope of the glacier front during the maximal Late Holocene advance. Taking into account their position, morphology, and difference in altitude with Late Holocene moraine ridges, the latter can be considered to date from the end of the Late Glacial (swisstopo, 2020). They were attributed respectively to the Egesen I (SPL 13) and Egesen II (SPL 12) stadials of the Eastern Alps and their respective ages would be ca. 12.50 and $11.20 \mathrm{kyr}$ b2k (Scapozza et al., 2014b).

The surface with the minimum $R$ value $(49 \pm 1.68)$ is that of the roches moutonnées at the Splügenpass (SPL 09), whereas the maximum $R$ value of $70 \pm 0.34$ was measured, as expected, on the fresh surface of recent fallen boulders (SPL 08). SPL 09 is significantly older and SPL 08 is significantly younger than all the other surfaces measured (except for SPL 09 with respect to SPL 13).

The surface of the Splügenpass rock glacier (SPL 01, 06, and 07 ) is significantly older than the two mule tracks crossing it (SPL 02 to 05). The relative surface age decreases significantly from the front to the rooting zone. On the historical mule tracks, measurements were carried out on the larger boulders, for both the retaining walls and the pavement. On the pavement, the selected boulders cover the en- tire width of the mule track; the resulting $R$ value should therefore be interpreted as the mean age of the surface and not necessarily as the age of the most abraded central sector. The retaining wall of the Roman period mule track (SPL 02) is significantly older than its pavement (SPL 03) as well as the retaining wall and the pavement of the Middle Age mule track (SPL 04 and 05), with the pavement being in turn significantly younger than its retaining wall. The exposure age of the lower mule track pavement corresponds to the age when this mule track was abandoned, because the abrasion exerted by travellers and pack animals has the effect of resetting the surface age. It is very interesting to note that the $R$-value range of SPL 03 and SPL 04 is partially superimposed, indicating that the relative surface age cannot be considered statistically different (even if SPL 03 appears to be slightly younger): this indicates the abandonment of the $300 \mathrm{CE}$ mule track just after the construction of the new one around $1250 \mathrm{CE}$.

The moraine ridges present significantly different $R$ values between those of the Late Holocene of the Suretta glacier (SPL 11), which is the youngest; those of the Early (?) Holocene damming the Bergseeli lake (SPL 10); and the two of the Late Glacial (SPL 12 and 13). The relative age of these two Late Glacial moraine ridges cannot be considered statistically different. 
Table 3. Schmidt hammer measurements performed in the Splügenpass area. RP-MT: Roman period mule track, built around 300 CE. MA-MT: High to Late Middle Ages mule track, built around $1250 \mathrm{CE}$.

\begin{tabular}{|c|c|c|c|c|c|c|c|}
\hline \multirow[t]{2}{*}{ Station } & \multicolumn{3}{|c|}{ Coordinates CH1903+/LV 95} & \multicolumn{3}{|c|}{$R$ value } & \multirow[t]{2}{*}{ Remarks } \\
\hline & East & North & $\begin{array}{l}\text { Altitude } \\
\text { (ma.s.1.) }\end{array}$ & Mean & $\begin{array}{l}\text { Standard } \\
\text { deviation }\end{array}$ & $\begin{array}{c}95 \% \\
\text { confidence } \\
\text { interval }\end{array}$ & \\
\hline SPL 01 & 2745280 & 1151940 & 2079 & 51 & 7 & \pm 1.90 & Rock glacier front \\
\hline SPL 02 & 2745390 & 1151950 & 2090 & 63 & 4 & \pm 0.92 & Wall of the RP-MT \\
\hline SPL 03 & 2745390 & 1151950 & 2090 & 66 & 4 & \pm 0.96 & Pavement of the RP-MT \\
\hline SPL 04 & 2745300 & 1151950 & 2095 & 65 & 3 & \pm 0.84 & Wall of the MA-MT \\
\hline SPL 05 & 2745300 & 1151950 & 2095 & 68 & 3 & \pm 0.64 & Pavement of the MA-MT \\
\hline SPL 06 & 2745330 & 1151960 & 2110 & 54 & 5 & \pm 1.33 & Centre of the rock glacier \\
\hline SPL 07 & 2745525 & 1152005 & 2205 & 61 & 4 & \pm 1.03 & Roots of the rock glacier \\
\hline SPL 08 & 2745525 & 1152005 & 2205 & 70 & 1 & \pm 0.34 & Recent ( $>2015$ CE) boulders \\
\hline SPL 09 & 2745415 & 1152365 & 2165 & 49 & 6 & \pm 1.68 & $\begin{array}{l}\text { Roches moutonnées of the } \\
\text { Splügenpass }\end{array}$ \\
\hline SPL 10 & 2745900 & 1152490 & 2320 & 56 & 6 & \pm 1.75 & $\begin{array}{l}\text { Early (?) Holocene moraine } \\
\text { ridge }\end{array}$ \\
\hline SPL 11 & 2747900 & 1151370 & 2560 & 59 & 5 & \pm 1.26 & $\begin{array}{l}\text { Late Holocene moraine ridge } \\
\text { of the Suretta glacier }\end{array}$ \\
\hline SPL 12 & 2747375 & 1150515 & 2065 & 52 & 4 & \pm 1.20 & $\begin{array}{l}\text { Late Glacial moraine ridge of } \\
\text { the Suretta glacier }\end{array}$ \\
\hline SPL 13 & 2747010 & 1150325 & 1963 & 51 & 4 & \pm 0.96 & $\begin{array}{l}\text { Late Glacial moraine ridge of } \\
\text { the Suretta glacier }\end{array}$ \\
\hline
\end{tabular}

\subsubsection{Exposure-age calibration}

A first attempt of Schmidt hammer exposure-age calibration was conducted using the age of the Late Glacial surfaces in the area (SPL 09, SPL 12, and SPL 13) and the $R$ value for unweathered surfaces (SPL 08), without taking into account the historical surfaces ("glacial calibration" in Table 4). Given that the $R$ value for the Late Holocene moraine ridge of the Suretta glacier (SPL 11) is significantly lower than the retaining wall of the Roman period, this surface of unknown precise age was not used for the calibration.

The resulting linear relationship between $R$ values and exposure age (kyr b2k) is

$R=\operatorname{kyr} \cdot(-1.3747)+69.398 \Leftrightarrow \mathrm{kyr}=\frac{R-69.398}{-1.3747}$,

with a coefficient of determination $\left(R^{2}\right)$ of 0.97 .

Compared to the historical known ages, the two mule tracks would result in too old of an age. The lower one would date $5.68-4.35 \mathrm{kyr}$ b2k (SPL 02), whereas the upper one would date 4.08-2.87 kyr b2k (SPL 04), corresponding to the Neolithic and the Bronze Age respectively. The re- cent boulders (SPL 08) would have fallen between 320 and 810 years after $2000 \mathrm{CE}$.

A second attempt of Schmidt hammer exposure-age calibration was then performed by considering only the measurement stations on the retaining walls of the Roman period (SPL 02, built around 300 CE) and of the Middle Ages (SPL 04, built around 1250 CE) mule tracks ("historical calibration" in Table 4).

The resulting linear relationship between $R$ value and exposure age $(\mathrm{kyr} b 2 \mathrm{k})$ is

$\mathrm{kyr}=\frac{R-66.290}{-2.2263}$.

This linear calibration based on the two historical artefacts did not provide Schmidt hammer exposure ages coherent with the glacial and periglacial regional history. The deglaciation of the Splügenpass (SPL 09), for example, cannot be dated at $8.55-7.04 \mathrm{kyr}$ b2k during the end of the Greenlandian and the beginning of the Northgrippian, which corresponds to the Holocene thermal maximum for the Southern Swiss Alps (Scapozza, 2019b). The argument is the same for the two Late Glacial moraines of the Suretta 
Table 4. Schmidt hammer exposure-age dating (SHD) on the Splügenpass area. The age-error calculation was based on the $95 \%$ confidence interval. In italics, aberrant values are shown projected into the future. The "glacial" calibration was performed by linear regression considering only measurement stations SPL 08, SPL 09, SPL 12, and SPL 13. The "historical calibration" was performed by linear regression considering only measurement stations SPL 02 and SPL 04. The "polynomial calibration" was performed considering all the measurement stations with an "attributed age". AA: attributed age; AE: age error; CI: confidence interval; CMA: calculated mean age; M: mean.

\begin{tabular}{|c|c|c|c|c|c|c|c|c|c|c|}
\hline \multirow[t]{4}{*}{ Station } & \multicolumn{2}{|c|}{$R$ value } & \multicolumn{8}{|c|}{ Chronology } \\
\hline & \multirow[t]{3}{*}{ M } & \multirow{3}{*}{$\begin{array}{c}95 \% \\
\mathrm{CI}\end{array}$} & \multirow{3}{*}{$\begin{array}{r}\text { AA } \\
(\mathrm{kyr} \\
\mathrm{b} 2 \mathrm{k})\end{array}$} & \multirow{2}{*}{\multicolumn{2}{|c|}{$\begin{array}{l}\text { "Glacial" } \\
\text { calibration }\end{array}$}} & \multirow{2}{*}{\multicolumn{2}{|c|}{$\begin{array}{l}\text { "Historical" } \\
\text { calibration }\end{array}$}} & \multicolumn{3}{|c|}{ "Polynomial" calibration } \\
\hline & & & & & & & & CMA & $\mathrm{AE}$ & Calculated age \\
\hline & & & & $\begin{array}{r}\text { CMA } \\
(\text { kyr b2k) }\end{array}$ & $\begin{array}{c}\mathrm{AE} \\
( \pm \mathrm{kyr})\end{array}$ & $\begin{array}{r}\text { CMA } \\
(\text { kyr b2k) }\end{array}$ & $\begin{array}{c}\mathrm{AE} \\
( \pm \mathrm{kyr})\end{array}$ & (kyrb2k) & $( \pm \mathrm{kyr})$ & (BCE/CE) \\
\hline SPL 01 & 51 & \pm 1.90 & - & 13.33 & 2.77 & 6.83 & 0.85 & 12.84 & 2.76 & $13750-8240 \mathrm{BCE}$ \\
\hline SPL 02 & 63 & \pm 0.92 & 1.70 & 5.01 & 1.33 & 1.70 & 0.41 & 1.57 & 0.48 & $80 \mathrm{BCE}-880 \mathrm{CE}$ \\
\hline SPL 03 & 66 & \pm 0.96 & - & 2.51 & 1.40 & 0.15 & 0.43 & 0.23 & 0.24 & $1490-1970 \mathrm{CE}$ \\
\hline SPL 04 & 65 & \pm 0.84 & 0.75 & 3.48 & 1.22 & 0.75 & 0.38 & 0.63 & 0.30 & 1040-1640 CE \\
\hline SPL 05 & 68 & \pm 0.64 & - & 1.05 & 0.94 & -0.75 & 0.29 & -0.11 & 0.06 & 2040-2150CE \\
\hline SPL 06 & 54 & \pm 1.33 & - & 11.13 & 1.94 & 5.48 & 0.60 & 8.85 & 1.60 & 8520-5310 BCE \\
\hline SPL 07 & 61 & \pm 1.03 & - & 5.96 & 1.50 & 2.28 & 0.46 & 2.32 & 0.65 & 1010 BCE-290 CE \\
\hline SPL 08 & 70 & \pm 0.34 & -0.02 & -0.57 & 0.50 & -1.75 & 0.15 & -0.10 & 0.03 & $2070-2130 C E$ \\
\hline SPL 09 & 49 & \pm 1.68 & 16.25 & 14.89 & 2.45 & 7.80 & 0.76 & 16.14 & 2.73 & $16990-11530 \mathrm{BCE}$ \\
\hline SPL 10 & 56 & \pm 1.75 & - & 9.44 & 2.55 & 4.43 & 0.79 & 6.26 & 1.78 & 6160-2600 BCE \\
\hline SPL 11 & 59 & \pm 1.26 & - & 7.28 & 1.83 & 3.10 & 0.57 & 3.60 & 0.98 & 2640-680 BCE \\
\hline SPL 12 & 52 & \pm 1.20 & 11.20 & 12.56 & 1.40 & 6.36 & 0.54 & 11.37 & 1.64 & 11 060-7790 BCE \\
\hline SPL 13 & 51 & \pm 0.96 & 12.50 & 13.05 & 1.75 & 6.66 & 0.43 & 12.30 & 1.36 & $11700-8980$ BCE \\
\hline
\end{tabular}

glacier (SPL 12 and SPL 13), which cannot be attributed to the Northgrippian. If this linear calibration clearly reproduces the exposure age of the two retaining walls, it is not the case for the pavement of the two mule tracks, which would result in dates between 1410 and $2280 \mathrm{CE}$ for that of the Roman period (SPL 03) and between 2460 and 3040 CE for that of the Middle Ages (SPL 05). The recent boulders (SPL 08) would have fallen in a distant future, between 3590 and 3900 CE.

A third attempt of Schmidt hammer exposure-age calibration was finally performed by taking into account Late Glacial surfaces (SPL 09, SPL 12, and SPL 13), the unweathered boulders (SPL 08), and the two historical artefacts (SPL 02 and SPL 04). Based on these six surfaces of attributed age, different approaches of $R$-value calibration were tested: as linear and exponential calibrations (not represented and discussed here) provided aberrant values, both for surfaces of known attributed age and for the coherence with the glacial and periglacial history on the area, a second-order polynomial regression was finally adopted ("polynomial calibration" in Table 4).

The regression equation between $R$ value and exposure age (kyr b2k) is

$\mathrm{kyr}=0.0403 R^{2}-5.5647 R+191.94$,

with a coefficient of determination $\left(R^{2}\right)$ of 1.00 .

This calibration is therefore not perfect because the upper mule track pavement was projected slightly off 40 150 years (SPL 05) into the future, while the recent boul- ders (SPL 08) would have fallen 70-130 years after 2000 CE. Despite this point, SHD allowed us to confirm the chronology of the Late Glacial glacier retreat and to date the Splügenpass rock glacier and talus slope development. SHD SPL 01 confirms a deglaciation of the Splügenpass before $15.75-10.24 \mathrm{kyr} 2 \mathrm{k}$. The exposure age of the last Late Glacial stadials of the Suretta glacier is of 14.46$10.98 \mathrm{kyr}$ b2k for Egesen I advance (SPL 13) and 13.06$9.79 \mathrm{kyr}$ b2k for Egesen II advance-stagnation (SPL 12). The moraine ridge damming the Bergseeli lake (SPL 10) presents an exposure age of 8.16-4.60 kyr b2k and can thus be correlated with the " $8.2 \mathrm{ka} \mathrm{BP}$ event" (Alley et al., 1997), which is dated $8.24 \mathrm{kyr}$ b2k and defines the passage from the Greenlandian to the Northgrippian (Walker et al., 2012). The exposure age of the Late Holocene moraine ridge of the Suretta glacier (SPL 11) is 4.64-2.68 kyr b2k and can be correlated with the Löbben cold oscillation (Burga et al., 2001), which is dated between 3.80 and $3.35 \mathrm{kyr}$ b2k in the Southern Swiss Alps (Scapozza, 2019b).

The Splügenpass rock glacier started its formation during the Late Glacial interstadial, as the minimum age of the front is $15.75-10.24 \mathrm{kyr} b 2 \mathrm{k}$ (SPL 01). The decreasing exposure age from the front to the rooting zone is typical for a rock glacier (e.g. compilation of SHD on rock glaciers in Scapozza, 2013; Winkler and Lambiel, 2018; Steinemann et al., 2020): on the centre of the formation (SPL 06) the exposure age is $10.52-7.31 \mathrm{kyr} b 2 \mathrm{k}$, whereas on the rooting zone (SPL 07) it is 3.01-1.71 kyr b2k (Fig. 7), highlighting a multi-millenary history of this relict rock glacier. 


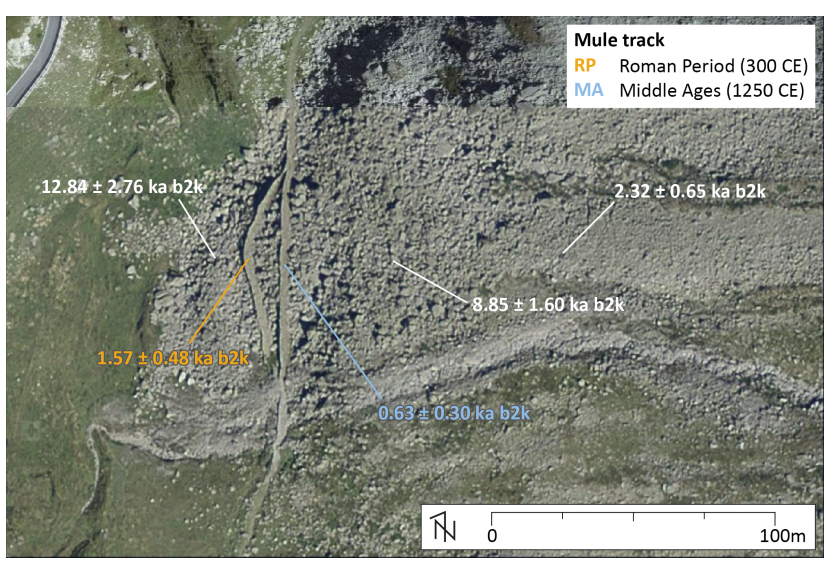

Figure 7. SHD performed on the surface of the Splügenpass rock glacier. Further details in the text. Orthophoto of 2018: (C) Swiss Federal Office of Topography swisstopo.

The SHD of the two mule tracks confirmed their chronological attribution to the Roman period and the High to Late Middle Ages (Fig. 7), even if the calculated ages are relatively wide-ranging: $2.08-1.12 \mathrm{kyr} b 2 \mathrm{k}$ (80 BCE-880 CE) for SPL 02 and 0.96-0.36 kyr b2k (1040-1640 CE) for SPL 04. The arched shape of the lower mule track is probably related to a differential deformation between the centre and the borders of the rock glacier, which indicates that it was probably still in movement after the lower mule track building during the Roman period. In contrast, the straight shape of the upper mule track and the absence of altitude drops outside the rock glacier perimeter indicate that the rock glacier stopped moving before its construction in the High and Late Middle Age. The final "relictification" of the Splügenpass rock glacier may thus be correlated with the Medieval Warm Period (1.15-0.70 kyr b2k = 850-1300 CE; Mann et al., 2009; Scapozza, 2019b). Considering the maximum deformation of $9.50 \mathrm{~m}$ at the centre of the rock glacier, which was produced in a maximum of 950 years, the corresponding mean horizontal velocity between 300 and $1250 \mathrm{CE}$ was $0.01 \mathrm{~m} \mathrm{yr}^{-1}$. The SHD of the Splügenpass rock glacier and of the retaining walls and pavements of the two mule tracks allows us to conclude that the alternative age attribution proposed by Merisio (2014), such as $1643 \mathrm{CE}$ for the lower mule track and $1716 \mathrm{CE}$ for the higher one, must therefore be definitively rejected.

\section{Discussion}

\section{1 $R$-value comparisons between the two study sites}

Despite the different lithological conditions between the Scaradra Valley and the Splügenpass region, a comparison of $R$ values measured in the two areas is possible. The maximum $R$ values for both study sites (69.31-70.69 for SCA 10 and 69.83-70.52 for SPL 08), expressing the exposure age of a fresh surface without weathering, is statistically superimposed. All the surfaces considered to be of the Pleistocene epoch or of the beginning of the Holocene epoch (SPL 01, SPL 09, SPL 12, and SPL 13, covering a range from 47.25 to 53.33) present an $R$ value significantly lower than those measured on moraines of the Scaradra glacier which are from the Late Holocene (SCA 02 to SCA 09, covering a range from 56.27 and 67.71). If the differentiation of $R$ values for the temporal extremes of our case studies (Pleistocene and last centuries of the Holocene) seems to be clear, the comparisons of $R$ values for most of the Holocene reveal higher uncertainties. The lowest $R$ value measured in the Scaradra glacier proglacial area (SCA 01: 52.18-53.82), in comparison with $R$ values measured in the Splügenpass region, would give the same exposure age of the centre of Splügenpass rock glacier (SPL 06: 52.76-55.43) and older than the moraine ridge of Bergseeli lake (SPL 10: 54.6758.18 ), which was attributed to the " $8.2 \mathrm{kaBP}$ " event (see Sect. 4.2.2). The $R$-value range of SCA 01 even intersects the range of the two Late Glacial moraine ridges SPL 12 (50.9353.33) and SPL 13 (50.50-52.42). Exclusively considering the $R$ values, it is not possible to exclude that moraine ridge SCA 01 could also be attributed to the Late Glacial.

On the contrary, the $R$ values measured on the two mule tracks crossing the Splügenpass rock glacier (SPL 02 to SPL 04, covering a range from 61.59 to 65.46) are within the range of $R$ values measured for moraine ridges SCA 04 to SCA 07 on the Scaradra glacier forefield (range of 61.2863.75), which were deposited between 1872 and $1922 \mathrm{CE}$ according to historical topographic maps.

This aspect of using surfaces of known historical age to differentiate $R$ values and calibrate Schmidt hammer exposure ages is what allows us to differentiate the two sites and, therefore, to propose the geomorphological and methodological arguments that will be discussed in the two following sections.

\subsection{Morphoclimatic events defined by SHD \\ 5.2.1 Biography of the Splügenpass rock glacier}

The exposure ages of the Splügenpass rock glacier and of the two historical mule tracks crossing its surface and the morphological analysis of the mule tracks' shape allowed the reconstruction of the rock glacier formation, development, and evolution. The minimum age of the front (SP 01: 15.75-10.24 kyr b2k) indicates that the development of the rock glacier began during or even before the Bølling-Allerød Late Glacial interstadial (14.50-12.90 ka cal BP). The maximum age of rock glacier formation corresponds with the minimum age of deglaciation of the Splügenpass, which is 18.99-13.53 kyr b2k (SPL 09). This beginning of development during the Late Glacial, in particular at the end of the Oldest Dryas (20.00-14.50 ka cal BP), is perfectly coherent with other rock glacier SHD performed in the Alps 


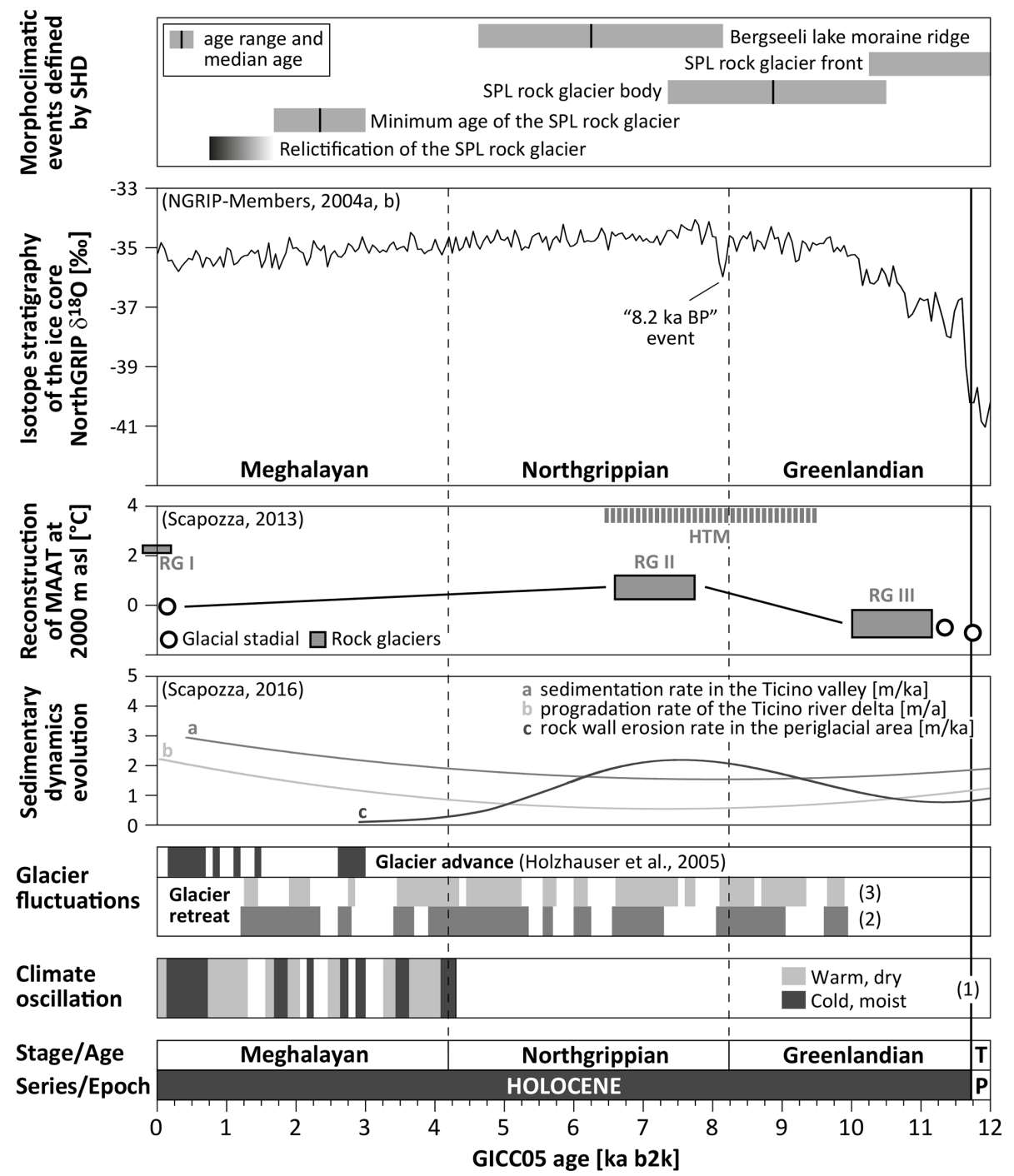

Figure 8. Events defined by SHD compared with the stratigraphy of the Holocene series/epoch and the Greenland isotope curve NorthGRIP (resulting from the combination of ice cores NorthGRIP 1 and 2) and correlation with the main morphoclimatic indicators defined for the Central and Southern Swiss Alps, compiled by Scapozza (2019b). Sources: (1) see "type of climate" in Fig. 9; (2) Hormes et al. (2006); (3) Joerin et al. (2006). Abbreviations: GICC05: Greenland Ice Core Chronology 2005; HTM: Holocene thermal maximum; MAAT: mean annual air temperature; P: Pleistocene; RG: generation of rock glaciers; SPL: Splügenpass; T: Tarentian (not yet ratified).

and allows us to include this rock glacier in the generation RG III (Scapozza, 2013, 2015; Scotti et al., 2017; Scapozza and Ambrosi, 2021; and references therein). If most cases rock glaciers of the generation RG III inactivated during the Greenlandian, before the Holocene thermal maximum, this is not the case for that of Splügenpass: SHD of the centre (SPL 06) indicates an important debris supply during the Holocene thermal maximum, whereas the SHD performed in the rooting zone (SPL 07) indicates a minimum age of debris supply comprised between 3.01 and $1.81 \mathrm{kyr}$ b2k (Figs. 8 and 9). The main debris volume in the middle and upper parts of the rock glacier was therefore deposited during the phase of enhanced rock wall erosion that occurred between the middle of the Greenlandian and the end of the Northgrippian (Fig. 8), when debris forming the main part of periglacial talus slopes and currently active and inactive rock glaciers were released (Scapozza, 2016). Finally, with the presence of the two mule tracks crossing its surface, it is possible to date the final inactivation/relictification of the Splügenpass rock glacier during the Medieval Warm Period (850-1300 CE according to Mann et al., 2009) just before the building of the upper mule track in $1250 \mathrm{CE}$. This result is very consistent with the ages of inactivation/relictification of some other rock glaciers obtained by radiocarbon dating, such as the Piancabella rock glacier in the Adula Alps (Fig. 9), for which the median age of inactivation is $1200 \mathrm{CE}$ (UZ-5545/ETH- 


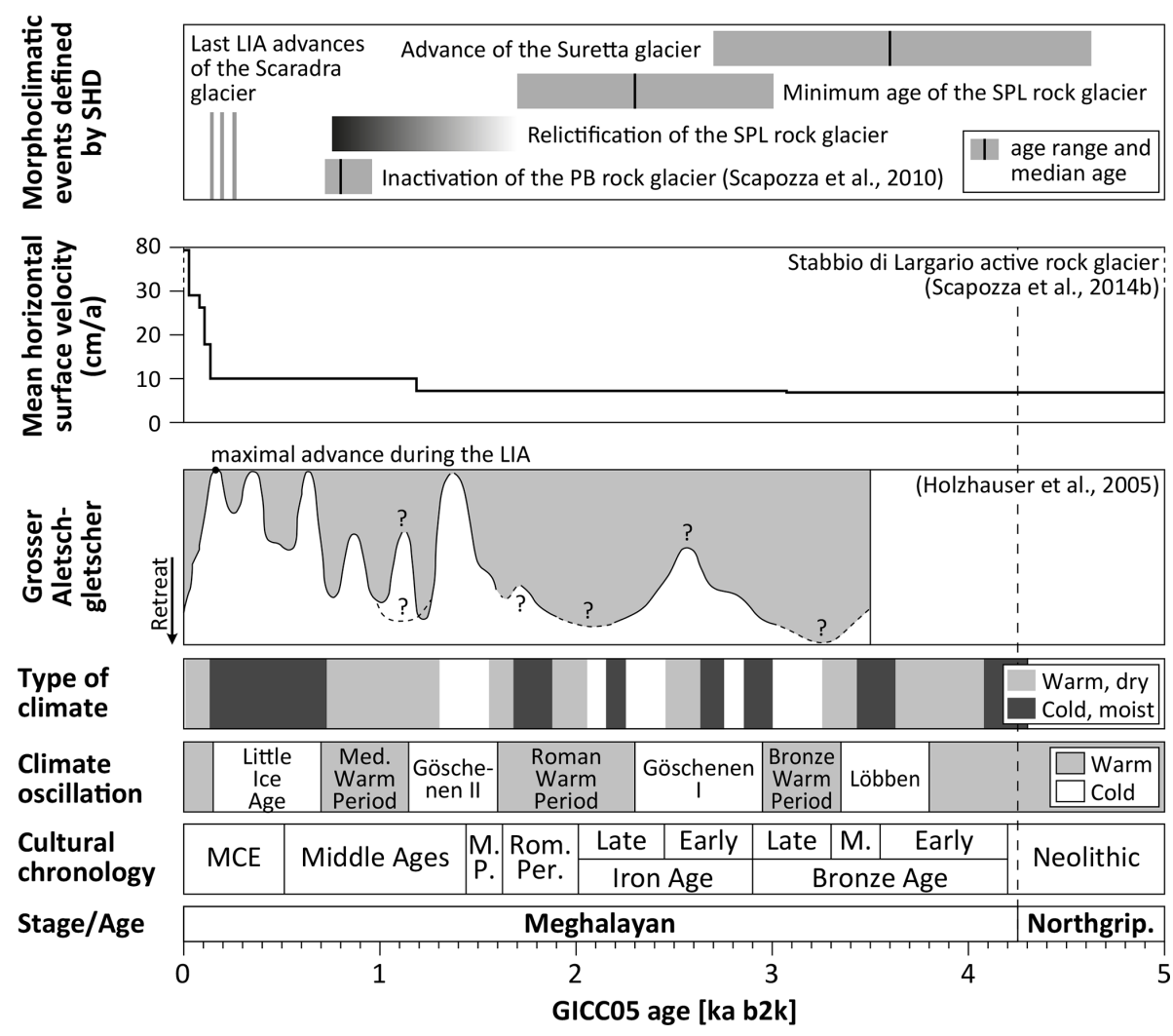

Figure 9. Events defined by SHD compared with the main morphoclimatic indicators defined for the central and Southern Swiss Alps during the Meghalayan stage/age (Upper-Late Holocene subseries/subepoch) compiled by Scapozza (2019b). Sources: type of climate from Tinner et al. (2003) for the period between $2300 \mathrm{BCE}$ and $800 \mathrm{CE}$, from Mann et al. (2009) for the Medieval Warm Period, and from Zumbühl and Holzhauser (1998) for the Little Ice Age; climate oscillations from Scapozza (2013) and from Patterson et al. (2010) for the Roman Warm Period; cultural chronology from Tinner et al. (2003) and from Carlevaro (2013) for the Late Bronze Age and the Iron Age. Abbreviations: GICC05: Greenland Ice Core Chronology 2005; LIA: Little Ice Age; M: middle; MCE: modern and contemporary epoch; M. P.: migration period; Northgrip.: Northgrippian; PB: Piancabella; Rom. Per.: Roman period; SPL: Splügenpass.

34417 in Table 5); the Val Maone rock glaciers in the Apennines (Italy), for which the median age of relictification is 1250 CE (BA-145530 in Table 5); and the Val di Rhêmes rock glacier in Aosta Valley (Western Italian Alps), for which the median age of relictification is $1310 \mathrm{CE}$ (GX-14741 in Table 5). The open question, which was not investigated here, is to understand how permafrost creep could be maintained in a rock glacier situated between 2080 and $2200 \mathrm{~m}$ a.s.l. up to the Medieval Warm Period. As a comparison with the two other rock glaciers relictified during the Medieval Warm Period, the front altitude of the Val Maone rock glacier in the Apennines is $2270 \mathrm{~m}$ a.s.l. (Giraudi, 2002), whereas the front altitude of the Val di Rhêmes rock glacier in Aosta Valley is 2480 m a.s.l. (Mortara et al., 1992).

\subsubsection{New evidence for Holocene glacier fluctuations}

The minimum age of the Bergseeli lake moraine ridge indicates that its formation may correspond to the " $8.2 \mathrm{ka} \mathrm{BP"}$ event, which began during the transition from the Greenlandian to the Northgrippian (Fig. 8). This glacial stadial is known in the Eastern Alps as the Kromer stadial (Kerschner et al., 2006) and has not yet been clearly recognised in the Southern Swiss Alps due to the lack of punctual dating of corresponding moraines (Scapozza, 2019b). SHD of moraine ridges correlated with the Kromer stadial were however performed in Val Cantone di Dosdé (Central Italian Alps), with an exposure age of 11.20-8.20 kyrb2k (M17) and 11.108.3 (M18) (Scotti et al., 2017).

An advance of the Suretta glacier corresponding to the Löbben cold oscillation was also evidenced (Fig. 9), highlighting the importance of this cold and moist period for the high-mountain morphogenesis during the prehistory. Based on SHD, Scotti et al. (2017) associated the starting of development of currently active rock glaciers with the Löbben oscillation. Palynostratigraphical evidence of the Löbben oscillation was found, in the Southern Swiss Alps and in Poschiavo and Blenio valleys (Burga et al., 2001); in contrast, no glacier advances, with the exception of that evidenced in this study, have been documented to date in this part of the Alps. 
Table 5. Compilation and calibration of radiocarbon ages discussed in the text. Calibration was performed with OxCal 4.4 software, using the IntCal 20 curve and with a $2 \sigma$ range (95.4\% of probability). Source: (1) Oeschger et al. (1970); (2) Zoller and Kleiber (1971); (3) Scapozza et al. (2010); (4) Giraudi (2002); (5) Dramis et al. (2003); (6) Mortara et al. (1992).

\begin{tabular}{|c|c|c|c|c|c|}
\hline Lab. code & Locality & $\begin{array}{r}\text { Conventional } \\
\text { age }\left[\mathrm{a}^{14} \mathrm{CBP}\right]\end{array}$ & $\begin{array}{l}\text { Calibrated age } \\
{[\text { cal BP] }}\end{array}$ & $\begin{array}{l}\text { Calibrated age } \\
{[\mathrm{BCE} / \mathrm{CE}]}\end{array}$ & Source \\
\hline B-874 & $\begin{array}{l}\text { Suossa (San Bernardino), } \\
\text { Graubünden, } \mathrm{CH}\end{array}$ & $13010 \pm 200$ & $16200-15010$ & $14250-13060$ BCE & $(1),(2)$ \\
\hline $\begin{array}{l}\text { UZ-5545/ } \\
\text { ETH-34417 }\end{array}$ & $\begin{array}{l}\text { Valle di Sceru, Adula } \\
\text { Alps, Ticino, } \mathrm{CH}\end{array}$ & $845 \pm 50$ & $\begin{array}{l}910-840(11.3 \%) \\
830-670(84.2 \%)\end{array}$ & $\begin{array}{l}1040-1110 \mathrm{CE}(11.3 \%) \\
1120-1280 \mathrm{CE}(84.2 \%)\end{array}$ & (3) \\
\hline BA-145530 & Val Maone, Apennines, I & $780 \pm 40$ & $780-660$ & $1170-1290 \mathrm{CE}$ & $(4),(5)$ \\
\hline GX-14741 & $\begin{array}{l}\text { Val di Rhêmes, Aosta } \\
\text { Valley, I }\end{array}$ & $670 \pm 180$ & $960-310$ & 990-1640 CE & (6) \\
\hline
\end{tabular}

Fluctuations of the Scaradra glacier in the last 3 centuries were assessed using high-resolution SHD and to comparisons with historical cartography (Fig. 9). For the first time, the SHD of the moraine ridge SCA 02 (1793-1817 CE) confirmed with an exposure age of 1817-1820 CE for the maximum advance during the end of the LIA in the Adula Alps. This endorses the palaeoclimatic reconstruction carried out by Pellegrini (1973), mainly based on dendrochronology and on historical documents on glacier fluctuations, and the recent integrations proposed by Scapozza (2013, 2019a), documenting a particularly cold climate followed by a glacier advance between 1811 and $1820 \mathrm{CE}$. The generalised mass increase in Alpine glaciers between 1810 and 1820 is well documented (Brönnimann, 2019; Huss and Förster, 2019). In the Western Swiss Alps, this was followed by a glacier retreat, whereas the mass increase was constant for the Central Swiss Alps until 1850-1860 CE (Holzhauser et al., 2005; Huss and Förster, 2019, and Fig. 9). The Scaradra glacier also presented a slight retreat after $1820 \mathrm{CE}$, with the advance of $1854 \mathrm{CE}$ being of lesser extent. Less evidence is presented on reference glacier fluctuation curves for the advance dated between 1726 and 1753 CE by SHD on SCA 01 moraine. The 18th century is normally considered a period of glacial retreat/stagnation between the main advances of 1600/40-1666/70 and 1820/22-1855/60 CE (Holzhauser et al., 2005 and Fig. 9). In the Adula Alps, however, the iconographic representations indicate a probable progression of the Paradiesgletscher (Rheinwald, Graubünden) in the period 1740-1759 CE and of the Läntagletscher (Valsertal, Graubünden) around 1776 CE (Scapozza, 2019a).

\section{3 $R$-value calibrations by historical data}

\subsubsection{Linear or non-linear calibration?}

Linear calibration of $R$ values constitutes the normal approach for obtaining Schmidt hammer exposure ages (e.g. Kellerer-Pirklbauer, 2008; Matthews and Owen, 2010; Shakesby et al., 2011; Scapozza, 2015; Winkler and Lambiel,
2018). Linear relationships between at least three surfaces of known age were found on two occasions even in the Adula Alps (Scapozza, 2013; Scapozza et al., 2014b). Concerning the Scaradra Valley case study where surfaces have been exposed for less than 3 centuries, the linear calibration of $R$ values yielded accurate exposure ages, which were found to be extremely coherent with the glacier retreat history since 1854 CE (Fig. 3 and Table 2). In contrast, a linear calibration for $R$ values measured in the Splügenpass region did not provide results consistent with the glacier history of the area. This inconsistency was obtained by considering only the moraine ridges of known or assumed age ("glacial calibration"), only the two historically dated surfaces ("historical calibration"), and all these elements together (Table 4).

A calibration curve allowing coherent exposure ages, both for the two mule tracks crossing the Splügenpass rock glacier and for the Late Glacial surfaces created by glaciers, was obtained only by using a second-order polynomial regression. This kind of regression has the advantage of being considered almost as linear between the three surfaces of the end of the Tarentian and beginning of the Greenlandian (SPL 09, SPL 12, SPL 13), as well as between the three surfaces of the Meghalayan (SPL 02, SPL 04, SPL 08). The linear behaviour between the three Meghalayan surfaces would have had the effect of providing a Northgrippian age of the older surfaces created during the deglaciation; vice versa, the linear behaviour between the three oldest surfaces would have had the effect of projecting recent historical surfaces several millennia into the future. Considering climatic differences between the Late Pleistocene and the Late Holocene, it is clear that the intensity of surface weathering (influencing the $R$ value) was not the same between these two subepochs.

It would have been possible to define the trend of weathering throughout the entire period if one or more surfaces of known age had been available for the Mid-Holocene, which was not the case. Indeed, if we look at the morphoclimatic indicators for erosion and sedimentation in the Southern Swiss Alps, the trend is never linear (Fig. 8 and Scapozza, 2019b), 
as shown for example by the sedimentation rates in the Ticino valley floodplain, the progradation rates of the Ticino and Verzasca river deltas, or the rock wall erosion rates in the periglacial area quantified by the volume and the age of development of rock glaciers and talus slopes (Scapozza, 2016; Scapozza and Ambrosi, 2021). The best-fitting statistical regression for these three indicators was obtained using a polynomial model, which was of the second order for the sedimentation and delta progradation rates (Scapozza, 2016). As a consequence, the second-order polynomial regression defined for the Splügenpass region using the historical surfaces probably reflects the evolution of surface weathering during time, which is characterised by the highest rates during the Late Glacial; very low rates during part of the Early Holocene and the Mid-Holocene, in correspondence with the Holocene thermal maximum; and an increase in the rates during the Late Holocene (Scapozza, 2016, and references therein).

\subsubsection{Which rebound(s) to consider?}

In this study, such as in similar studies conducted by the first author in Ticino and Valais Cantons (e.g. Scapozza, 2013, 2015; Scapozza et al., 2014b), the mean $R$ value for every measurement station is based on the mean of the second and third consecutive impacts for every reading. This does not respect the principle of the method, which is based on the exclusive interpretation of the first impact (e.g. KellererPirklbauer, 2008; Shakesby et al., 2011; Scotti et al., 2017; Winkler and Lambiel, 2018). This methodological difference is based on the consideration, presented and discussed in Scapozza (2013) on the basis of the compilation of 6390 series of four impacts, that the first impact is highly perturbed by the presence of dust, micro-lichens, and other impurities on the rock surface. Indeed, the difference between the mean of impacts 2 and 3 and impact 1 is not linear with time: it increases with the decrease in the $R$ value, i.e. with the augmentation of the exposure age. The same behaviour was observed for the 500 readings collected in the Scaradra Valley and the 650 readings collected in the Splügenpass region (for further details see Fig. A1). On the single readings, the difference between the first impact and the mean of impacts 2 and 3 is comprised in mean between 7.4 (SCA) and 7.7 (SPL) and between 32.0 (SCA) and 37.8 (SPL) for the maximum difference. For the mean $R$ values based on the 50 readings of a single measurement station, the difference is similar in mean ( 7.5 for SCA and 7.7 for SPL), whereas it is logically less extended for the maximum difference (10.0 for SCA and 13.6 for SPL). If expressed in terms of exposure age, the mean and maximum differences correspond to 8.2 and $10.0 \mathrm{kyr}$ respectively for the Scaradra Valley and to 3.22 and $3.82 \mathrm{kyr}$ respectively for the Splügenpass region (for this last case study, starting from a mean $R$ value for the first impact of 60).
In order to understand which one of the two approaches is the most suitable for the data processing, it is therefore important to compare the results obtained by considering the mean of impacts 2 and 3 or only the first impact (for further details see data in Appendices). For the Scaradra Valley, the $R$-value calibration based on the first impact (Table A2) gives dates coherent with the historical cartography. The only difference is for SCA 01 and SCA 02, which are respectively dated 1178-1799 and 1835-1852 CE. These two are probably dated too young with respect to the local glacier history discussed in Sect. 5.2.2. The small difference between the results obtained from the two approaches is probably related to the recent exposure ages (less than 3 centuries) and the relatively low difference in $R$ values between the first and the third impacts (Fig. A1a). This is not the case for the Splügenpass region, where the calibrated exposure ages obtained from the first impact for the more recent surfaces are projected several decades, even centuries, into the future (Table A4). This is the case for SPL 03 (2240-2680 CE), SPL 05 (2100-2730 CE), and SPL 08 (2050-2680) measurement stations, whose exposure age is certainly comprised between 1250 CE (SPL 03) and today (SPL 05 and SPL 08). Even the calculated age for the retaining wall of the High and Late Middle Ages mule track (SPL 04) is not reproduced, because the calibrated age of $130 \mathrm{BCE}-1030 \mathrm{CE}$ is significantly older than the attributed date of $1250 \mathrm{CE}$.

\section{Conclusion}

Four main conclusions can be drawn from the observations and measurements at the two study sites.

1. Schmidt hammer exposure-age calibration based on historical surfaces of known age allowed definition of a linear regression for the recent surfaces dated in the Scaradra Valley (assessed using historical cartography) and a second-order polynomial regression for the postdeglaciation surfaces dated in the Splügenpass region (assessed using two mule tracks built around 300 and $1250 \mathrm{CE}$, respectively), which are consistent with the morphoclimatic history of the Southern Swiss Alps known until today.

2. The Splügenpass relict rock glacier started its development between 15.75 and $10.24 \mathrm{kyr} b 2 \mathrm{k}$, just after the deglaciation of the Splügenpass, which was dated $18.99-13.53 \mathrm{kyr} b 2 \mathrm{k}$. The main debris volume in the middle and upper parts of the rock glacier was deposited between 10.52-7.31 and 3.01-1.71 kyrb2k, probably corresponding to the Holocene thermal maximum. The rock glacier probably became relict during the Medieval Warm Period, as indicated by the arched shape of the Roman period mule track, which was deformed by the displacement, and the rectilinear shape of the upper mule track built in $1250 \mathrm{CE}$. 
3. Geochronological evidence of glacier fluctuations corresponding to the " $8.2 \mathrm{kaBP}$ " event (SHD of 8.16$8.40 \mathrm{kyr} b 2 \mathrm{k}$ of the moraine SPL 10 damming the Bergseeli lake) and the Palü cold oscillation (SHD of $4.64-2.68 \mathrm{kyr} 2 \mathrm{k}$ of the moraine SPL 11 of the Suretta glacier) is presented for the first time for the Lepontine Alps. The SHD of 1793-1817 CE of the moraine ridge SCA 02 of the Scaradra glacier allowed us to confirm the maximum end of the LIA advance during the period 1817-1820 CE in the Adula Alps with an exposure age, endorsing the palaeoclimatic reconstructions carried out in this region in the last decades.

4. The comparison between the SHD, which is based on the calibration of $R$ values derived from the analysis of the mean of the second and third impacts and of the first impact, has allowed us to show the greater robustness of the first approach. If the two approaches do not present significant differences for measuring stations on the Scaradra glacier forefield, because of recent exposure ages (less than 3 centuries), the calibrated exposure ages obtained for the Splügenpass region from the first impact for the more recent surfaces are projected several decades, even centuries, into the future. Considering the two artefacts of known age, only the first approach allowed the reproduction of a statistically significant age.

\section{Appendix A}

This section presents $R$ values and SHD based exclusively on the first impact for every reading. The difference between $R$ value for the first impact and the mean $R$ value for impacts 2 and 3 is presented in Fig. A1.

For the Scaradra Valley ( $R$ values in Table $\mathrm{A} 1$ and exposure ages in Table A2), the resulting relationship between $R$ value and the exposure age ( $\mathrm{yr} \mathrm{b} 2 \mathrm{k})$ is

$\mathrm{yr}=\frac{R-64.354}{-0.0915}$.

For the Splügenpass regions ( $R$ values in Table $\mathrm{A} 3$ and calibrated exposure ages in Table A4), the "glacial calibration" was performed by linear regression considering only measurement stations SPL 08, SPL 09, SPL 12, and SPL 13. The resulting linear relationship between $R$ value and the exposure age (kyr b2k) for the "glacial calibration" is

$\mathrm{kyr}=\frac{R-61.381}{-1.5022}$,

with a coefficient of determination $\left(R^{2}\right)$ of 0.88 .
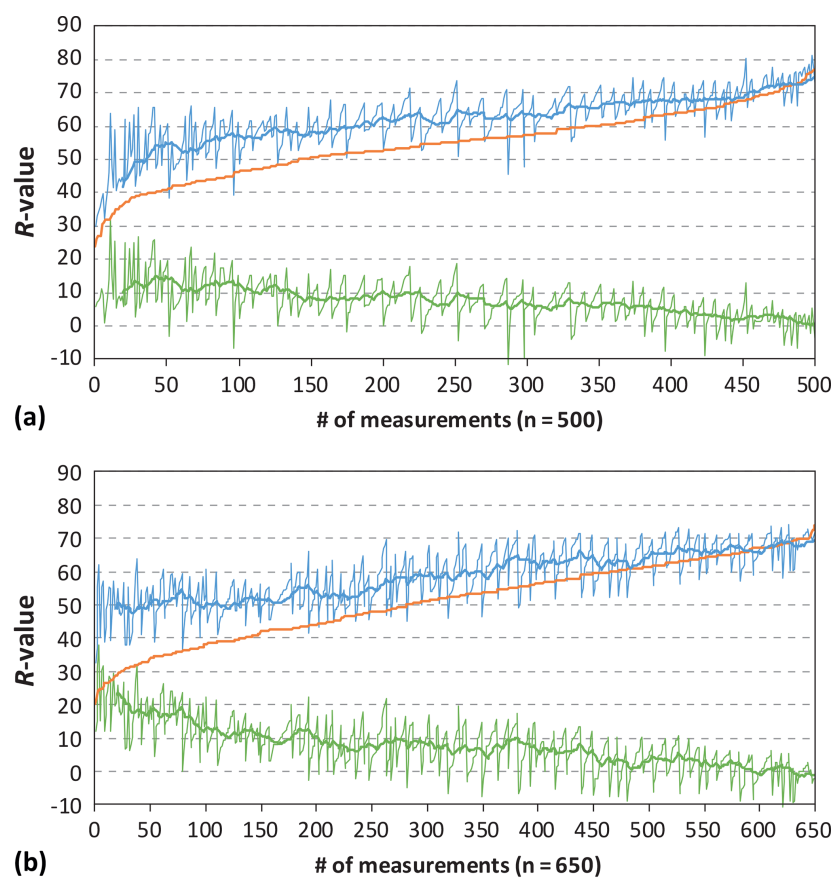

\begin{tabular}{lll}
\hline - impact 1 (IMP1) & - mean of IMP2-3 & - mean IMP2-3 - IMP1 \\
& - 20 data moving mean & - 20 data moving mean
\end{tabular}

Figure A1. Difference between the first impact (IMP1) and the mean of impacts 2 and 3 (IMP2-3) for the measurement points sampled in this study: (a) Scaradra Valley and (b) Splügenpass region.

The "historical calibration" was performed by linear regression considering only measurement stations SPL 02 and SPL 04. The resulting linear relationship between $R$ value and the exposure age (kyr b2k) for the "historical calibration" is

$\mathrm{kyr}=\frac{R-58.199}{-0.9053}$.

The equation for the second-order polynomial regression between $R$ value (considering stations SPL 02, 04, 08, 09, 12, and 13) and the exposure age (kyr b2k) is

$\mathrm{kyr}=0.0161 R^{2}-2.2820 R+79.5160$,

with a coefficient of determination $\left(R^{2}\right)$ of 0.92 . 
Table A1. Schmidt hammer measurements performed on the Scaradra glacier proglacial area. $R$ values obtained by considering only the first impact for every reading (50 first impacts, 10 per boulder, for every measurement station). LIA: 1350-1860 according to Zumbühl and Holzhauser (1988).

\begin{tabular}{|c|c|c|c|c|c|c|c|}
\hline \multirow[t]{2}{*}{ Station } & \multicolumn{3}{|c|}{ Coordinates CH1903+/LV 95} & \multicolumn{3}{|c|}{$R$ value } & \multirow[t]{2}{*}{ Remarks } \\
\hline & East & North & $\begin{array}{l}\text { Altitude } \\
\text { (ma.s.1.) }\end{array}$ & Mean & $\begin{array}{r}\text { Standard } \\
\text { deviation }\end{array}$ & $\begin{array}{c}95 \% \\
\text { confidence } \\
\text { interval }\end{array}$ & \\
\hline SCA 01 & 2720125 & 1156890 & 2181 & 45 & 8 & \pm 0.95 & $\begin{array}{l}\text { Early Holocene (?) moraine } \\
\text { ridge covered by lichens }\end{array}$ \\
\hline SCA 02 & 2720135 & 1156850 & 2185 & 50 & 11 & \pm 0.78 & $\begin{array}{l}\text { External LIA moraine ridge } \\
(1818-1820 ? \mathrm{CE})\end{array}$ \\
\hline SCA 03 & 2720120 & 1156800 & 2191 & 51 & 8 & \pm 0.76 & LIA moraine ridge $(1854 \mathrm{CE})$ \\
\hline SCA 04 & 2720145 & 1156775 & 2192 & 52 & 8 & \pm 0.69 & LIA moraine ridge \\
\hline SCA 05 & 2720160 & 1156750 & 2194 & 56 & 7 & \pm 0.79 & Post-LIA moraine ridge \\
\hline SCA 06 & 2720180 & 1156705 & 2196 & 51 & 7 & \pm 0.87 & Post-LIA moraine ridge \\
\hline SCA 07 & 2720200 & 1156660 & 2198 & 56 & 8 & \pm 0.79 & Post-LIA moraine ridge \\
\hline SCA 08 & 2720195 & 1156600 & 2203 & 61 & 7 & \pm 0.73 & Post-LIA moraine ridge \\
\hline SCA 09 & 2720210 & 1156355 & 2216 & 59 & 8 & \pm 0.71 & 20 th century moraine ridge \\
\hline SCA 10 & 2720260 & 1156115 & 2260 & 66 & 7 & \pm 0.73 & $\begin{array}{l}\text { Recently (2018 CE) } \\
\text { deglaciated area }\end{array}$ \\
\hline
\end{tabular}

Table A2. Schmidt hammer exposure-age dating (SHD) on the Scaradra glacier proglacial area, based on age calibration of $R$ values obtained by considering only the first impact for every reading (50 first impacts, 10 per boulder, for every measurement station). In italics, aberrant values are shown projected into the future.

\begin{tabular}{|c|c|c|c|c|c|c|}
\hline \multirow[t]{2}{*}{ Station } & \multicolumn{2}{|c|}{$R$ value } & \multicolumn{4}{|c|}{ Chronology } \\
\hline & Mean & $\begin{array}{c}95 \% \\
\text { confidence } \\
\text { interval }\end{array}$ & $\begin{array}{r}\text { Attributed } \\
\text { age }(\mathrm{yr} \text { b2k) }\end{array}$ & $\begin{array}{r}\text { Calculated } \\
\text { mean age } \\
(\mathrm{yr} \text { b2k) }\end{array}$ & $\begin{array}{r}\text { Age } \\
\text { error } \\
( \pm \text { yr })\end{array}$ & $\begin{array}{c}\text { Calculated } \\
\text { age (CE) }\end{array}$ \\
\hline SCA 01 & 45 & \pm 0.95 & - & 212 & 10 & 1778-1799 \\
\hline SCA 02 & 50 & \pm 0.78 & - & 157 & 9 & 1835-1852 \\
\hline SCA 03 & 51 & \pm 0.76 & 146 & 146 & 8 & $1846-1862$ \\
\hline SCA 04 & 52 & \pm 0.69 & - & 135 & 8 & $1857-1873$ \\
\hline SCA 05 & 56 & \pm 0.79 & - & 91 & 9 & 1900-1917 \\
\hline SCA 06 & 51 & \pm 0.87 & - & 146 & 10 & 1845-1864 \\
\hline SCA 07 & 56 & \pm 0.79 & - & 91 & 9 & 1900-1911 \\
\hline SCA 08 & 61 & \pm 0.73 & - & 37 & 8 & 1955-1971 \\
\hline SCA 09 & 59 & \pm 0.71 & - & 59 & 8 & 1934-1949 \\
\hline SCA 10 & 66 & \pm 0.73 & -18 & -18 & 8 & 2010-2026 \\
\hline
\end{tabular}


Table A3. Schmidt hammer measurements performed in the Splügenpass area. $R$ values obtained by considering only the first impact for every reading (50 first impacts, 10 per boulder, for every measurement station). RP-MT: Roman period mule track, built around 300 CE; MA-MT: High to Late Middle Ages mule track, built around 1250 CE.

\begin{tabular}{|c|c|c|c|c|c|c|c|}
\hline \multirow[t]{2}{*}{ Station } & \multicolumn{3}{|c|}{ Coordinates CH1903+/LV 95} & \multicolumn{3}{|c|}{$R$ value } & \multirow[t]{2}{*}{ Remarks } \\
\hline & East & North & $\begin{array}{l}\text { Altitude } \\
\text { (ma.s.1.) }\end{array}$ & Mean & $\begin{array}{l}\text { Standard } \\
\text { deviation }\end{array}$ & $\begin{array}{c}95 \% \\
\text { confidence } \\
\text { interval }\end{array}$ & \\
\hline SPL 01 & 2745280 & 1151940 & 2079 & 39 & 8 & \pm 2.22 & Rock glacier front \\
\hline SPL 02 & 2745390 & 1151950 & 2090 & 57 & 7 & \pm 1.78 & Wall of the RP-MT \\
\hline SPL 03 & 2745390 & 1151950 & 2090 & 64 & 4 & \pm 0.94 & Pavement of the RP-MT \\
\hline SPL 04 & 2745300 & 1151950 & 2095 & 58 & 5 & \pm 1.35 & Wall of the MA-MT \\
\hline SPL 05 & 2745300 & 1151950 & 2095 & 63 & 5 & \pm 1.29 & Pavement of the MA-MT \\
\hline SPL 06 & 2745330 & 1151960 & 2110 & 41 & 9 & \pm 2.89 & Centre of the rock glacier \\
\hline SPL 07 & 2745525 & 1152005 & 2205 & 55 & 9 & \pm 2.66 & Roots of the rock glacier \\
\hline SPL 08 & 2745525 & 1152005 & 2205 & 63 & 5 & \pm 1.27 & Recent ( $>2015$ CE) boulders \\
\hline SPL 09 & 2745415 & 1152365 & 2165 & 42 & 6 & \pm 1.85 & $\begin{array}{l}\text { Roches moutonnées of the } \\
\text { Splügenpass }\end{array}$ \\
\hline SPL 10 & 2745900 & 1152490 & 2320 & 50 & 10 & \pm 3.01 & $\begin{array}{l}\text { Early Holocene (?) moraine } \\
\text { ridge }\end{array}$ \\
\hline SPL 11 & 2747900 & 1151370 & 2560 & 55 & 5 & \pm 1.47 & $\begin{array}{l}\text { Late Holocene moraine ridge } \\
\text { of the Suretta glacier }\end{array}$ \\
\hline SPL 12 & 2747375 & 1150515 & 2065 & 41 & 6 & \pm 1.73 & $\begin{array}{l}\text { Late Glacial moraine ridge of } \\
\text { the Suretta glacier }\end{array}$ \\
\hline SPL 13 & 2747010 & 1150325 & 1963 & 40 & 7 & \pm 2.75 & $\begin{array}{l}\text { Late Glacial moraine ridge of } \\
\text { the Suretta glacier }\end{array}$ \\
\hline
\end{tabular}


Table A4. Schmidt hammer exposure-age dating (SHD) on the Splügenpass area, based on age calibration of $R$ values obtained by considering only the first impact for every reading ( 50 first impacts, 10 per boulder, for every measurement station). In italics, aberrant values projected into the future. The "glacial" calibration was performed by linear regression considering only measurement stations SPL 08, SPL 09, SPL 12, and SPL 13. The "historical calibration" was performed by linear regression considering only measurement stations SPL 02 and SPL 04. The "polynomial calibration" was performed considering all the measurement stations with an "attributed age". AA: attributed age; AE: age error; CI: confidence interval; CMA: calculated mean age; M: mean.

\begin{tabular}{|c|c|c|c|c|c|c|c|c|c|c|}
\hline \multirow[t]{4}{*}{ Station } & \multicolumn{2}{|c|}{$R$ value } & \multicolumn{8}{|c|}{ Chronology } \\
\hline & \multirow[t]{3}{*}{ M } & \multirow{3}{*}{$\begin{array}{c}95 \% \\
\mathrm{CI}\end{array}$} & \multirow{3}{*}{$\begin{array}{r}\mathrm{AA} \\
(\mathrm{kyr} b 2 \mathrm{k})\end{array}$} & \multicolumn{2}{|c|}{ "Glacial” } & \multicolumn{2}{|c|}{ "Historical" } & \multicolumn{3}{|c|}{ "Polynomial" calibration } \\
\hline & & & & \multicolumn{2}{|c|}{ Calibration } & \multicolumn{2}{|c|}{ Calibration } & \multirow{2}{*}{$\begin{array}{r}\text { CME } \\
(\mathrm{kyr} b 2 \mathrm{k})\end{array}$} & \multirow{2}{*}{$\begin{array}{c}\mathrm{AE} \\
( \pm \mathrm{kyr})\end{array}$} & \multirow{2}{*}{$\begin{array}{l}\text { Calculated age } \\
\text { (BCE/CE) }\end{array}$} \\
\hline & & & & $\begin{array}{r}\text { CMA } \\
(\mathrm{kyr} b 2 \mathrm{k})\end{array}$ & $\begin{array}{c}\mathrm{AE} \\
( \pm \mathrm{kyr})\end{array}$ & $\begin{array}{r}\text { CMA } \\
(\text { kyr b2k) }\end{array}$ & $\begin{array}{c}\mathrm{AE} \\
( \pm \mathrm{kyr})\end{array}$ & & & \\
\hline SPL 01 & 39 & \pm 2.22 & - & 14.93 & 2.96 & 21.26 & 2.45 & 15.06 & 2.28 & $15420-10860 \mathrm{BCE}$ \\
\hline SPL 02 & 57 & \pm 1.78 & 1.70 & 3.14 & 2.37 & 1.70 & 1.96 & 1.90 & 0.81 & $770 \mathrm{BCE}-860 \mathrm{CE}$ \\
\hline SPL 03 & 64 & \pm 0.94 & - & -1.42 & 1.26 & -5.87 & 1.04 & -0.47 & 0.22 & $2240-2680 C E$ \\
\hline SPL 04 & 58 & \pm 1.35 & 0.75 & 2.57 & 1.80 & 0.75 & 1.49 & 1.52 & 0.58 & $130 \mathrm{BCE}-1030 \mathrm{CE}$ \\
\hline SPL 05 & 63 & \pm 1.29 & - & -1.32 & 1.72 & -5.71 & 1.43 & -0.44 & 0.31 & $2100-2730 C E$ \\
\hline SPL 06 & 41 & \pm 2.89 & - & 13.89 & 3.85 & 19.53 & 3.19 & 13.48 & 2.82 & $14440-8800$ BCE \\
\hline SPL 07 & 55 & \pm 2.66 & - & 4.27 & 3.54 & 3.58 & 2.94 & 2.73 & 1.36 & $2200 \mathrm{BCE}-520 \mathrm{CE}$ \\
\hline SPL 08 & 63 & \pm 1.27 & -0.02 & -1.19 & 1.70 & -5.49 & 1.41 & -0.39 & 0.32 & $2050-2680 C E$ \\
\hline SPL 09 & 42 & \pm 1.85 & 16.25 & 13.23 & 2.46 & 18.45 & 2.04 & 12.54 & 1.75 & $12350-8850$ BCE \\
\hline SPL 10 & 50 & \pm 3.01 & - & 7.89 & 4.01 & 9.58 & 3.33 & 5.99 & 2.07 & 6200-2060 BCE \\
\hline SPL 11 & 55 & \pm 1.47 & - & 4.03 & 1.96 & 3.18 & 1.62 & 2.55 & 0.74 & $1320 \mathrm{BCE}-150 \mathrm{CE}$ \\
\hline SPL 12 & 41 & \pm 1.73 & 11.20 & 13.78 & 2.31 & 19.35 & 1.92 & 13.33 & 1.69 & 13 060-9690 BCE \\
\hline SPL 13 & 40 & \pm 2.75 & 12.50 & 14.11 & 3.66 & 19.89 & 3.04 & 13.81 & 2.72 & $14650-9210$ BCE \\
\hline
\end{tabular}


Data availlability. All relevant data are included in the article.

Author contributions. Investigation and formal analysis for the Scaradra Valley case study were performed by CDS and CS and supervised by CL. Investigation and formal analysis for the Splügenpass case study were performed by CS and CA. CS prepared the manuscript with contributions from all co-authors.

Competing interests. The authors declare that they have no conflict of interest.

Disclaimer. Publisher's note: Copernicus Publications remains neutral with regard to jurisdictional claims in published maps and institutional affiliations.

Acknowledgements. A special thanks to Nicola Deluigi for aiding in the measurement collection in the Scaradra Valley and to Daphné Giacomazzi for the digital Quaternary cartography of the Splügenpass region and for proofreading the English of a previous version and supporting the authors in the revision of the manuscript. The manuscript was substantially improved thanks to John A. Matthews, two other anonymous reviewers, and Nikolaus J. Kuhn as the handling editor.

Review statement. This paper was edited by Nikolaus J. Kuhn and reviewed by three anonymous referees.

\section{References}

Alley, R. B., Mayewski, P. A., Sowers, T., Stuiver, M., and Taylor K. C.: Holocene climatic instability: a prominent, widespread event $8200 \mathrm{yr}$ ago, Geology, 25, 483-486, https://doi.org/10.1130/00917613(1997)025<0483:HCIAPW>2.3.CO;2, 1997.

Brönnimann, S.: Temps et climat en Suisse dans les années 1810, Ann. Valais., 2019, 49-60, 2019.

Burga, C., Perret, R., and Zoller, H.: Swiss localities of early recognized Holocene climate oscillations - characterisation and significance, Vier. Natur. Gesell. Zürich, 146, 65-74, 2001.

Carlevaro, E.: Dinamiche del popolamento nell'area sudalpina dal Bronzo finale alla romanizzazione, Università di Zurigo, Zurigo, Svizzera, 343 pp., available at: https://zora.uzh.ch/id/ eprint/164250/ (last access: 9 November 2021), 2013.

Cavargna-Sani, M., Epard, J.-L., Bussy, F., and Ulianov, A.: Basement lithostratigraphy of the Adula nappe: implications for Palaeozoic evolution and Alpine kinematics, Int. J. Earth Sci., 103, 61-82, https://doi.org/10.1007/s00531-013-0941-1, 2014.

Del Siro, C.: Les fluctuations des glaciers après le Petit Âge Glaciaire, Datation de cordons morainiques dans le Val Scaradra avec la méthode du marteau de Schmidt et l'analyse de cartes historiques, Université de Lausanne, Lausanne, Suisse, 41 pp., 2019.

Dramis, F., Giraudi, C., and Guglielmin, M.: Rock glacier distribution and paleoclimate in Italy, in: ICOP 2003 Permafrost, edited by: Arenson, L. U., Phillips, M., and Springman, S., Taylor and Francis Group, London, UK, 199-204, 2003.

Giraudi, C.: I rock glacier tardo-pleistocenici ed olocenici dell'Appennino - Età, distribuzione, significato paleoclimatico, It. J. Quatern. Sci., 15, 45-52, 2002.

Goudie, A. S.: The Schmidt Hammer in geomorphological research, Prog. Phys. Geogr., 30, 703-718, https://doi.org/10.1177/0309133306071954, 2006.

Holzhauser, H., Magny, M., and Zumbühl, H. J.: Glacier and lake-level variations in west-central Europe over the last 3500 years, Holocene, 16, 789-801, https://doi.org/10.1191/0959683605hl853ra, 2005.

Hormes, A., Beer, J., and Schlüchter, C.: A geochronological approach to understanding the role of solar activity on Holocene glacier length variability in the Swiss Alps, Geogr. Ann. A, 88, 282-294, https://doi.org/10.1111/j.0435-3676.2006.00301.x, 2006.

Huss, M, and Förster, S.: L'avancée et le recul des glaciers pendant le Petit Age glaciaire, Ann. Valais., 2019, 225-232, 2019.

IVS Dokumentation Kanton Graubünden: Strecke GR 17, Splügen - Splügenberg (- Chiavenna); Splügenpass, Inventar Historischer Verkehrswege der Schweiz, Bern, Schweiz, 3 pp., 1992 a.

IVS Dokumentation Kanton Graubünden: Strecke GR 17.1, Splügen - Splügenberg (- Chiavenna); Splügenpass, Linienführung 1, Saumweg, Inventar Historischer Verkehrswege der Schweiz, Bern, Schweiz, 7 pp., 1992 b.

Joerin, U. E., Stocker, T. F., and Schlüchter, C.: Multicentury glacier fluctuations in the Swiss Alps during the Holocene, Holocene, 16, 697-704, https://doi.org/10.1191/0959683606hl964rp, 2006.

Kamleitner, S., Ivy-Ochs, S., Scapozza C., and Christl, M.: Early Lateglacial ice decay in Swiss main Valleys. Glacier retreat into Rhine \& Ticino Valley at the end of the last glaciation, Annual Report 2020, Ion Beam Physics, ETH Zurich, Zurich, Switzerland, p. 48, available at: https://ams. ethz.ch/publications/annual-reports/2017-to-2020.html (last access: 12 November 2021), 2020.

Kellerer-Pirklbauer, A.: The Schmidt-hammer as a relative age dating tool for rock glacier surfaces: examples from Northern and Central Europe, in: Ninth International Conference on Permafrost. 2. Frozen ground - Congresses, edited by: Kane, D. L., and Hinkel, K. M., Institute of Northern Engineering, University of Alaska, Fairbanks, 913-918, 2008.

Kerschner, H., Hertl, A., Gross, G., Ivy-Ochs, S., and Kubik, P. W.: Surface exposure dating of moraines in the Kromer valley (Silvretta Mountains, Austria) - evidence for glacial response to the $8.2 \mathrm{ka}$ event in the Eastern Alps?, Holocene, 16, 7-15, https://doi.org/10.1196/0959683606hl902rp, 2006.

Lambiel, C.: Glacial and periglacial landscapes in the Hérens Valley, in: Landscapes and Landforms of Switzerland, edited by: Reynard, E., Springer Nature, Cham, Switzerland, 263-275, https://doi.org/10.1007/978-3-030-43203-4_18, 2021.

Maisch M.,: Die Gletschers Graubündens, Geographisches Institut der Universität Zürich, Physische Geographie, 33, 2, 1992.

Mann, M. E., Zhang, Z., Rutherford, S., Bradley R. S., Hughes, M. K., Shindell, D., Ammann, C., Faluvegi, G., and Fenbiao, N.: Global signatures and dynamical origins of the Little Ice Age and Medieval Climate Anomaly, Science, 326, 1256-1260, https://doi.org/10.1126/science.1177303, 2009. 
Matthews, J. A. and Owen, H.: Schmidt hammer exposureage dating: developing linear age-calibration curves using Holocene bedrock surfaces from the JotunheimenJostedalsbreen regions of southern Norway, Boreas, 39, 105-115, https://doi.org/10.1111/j.1502-3885.2009.00107.x, 2010.

Matthews, J. A. and Winkler, S.: Schmidt-hammer exposureage dating (SHD): application to early Holocene moraines and a reappraisal of the reliability of terrestrial cosmogenicnuclide dating (TCND) at Austanbotnbreen, Jotunheimen, Norway, Boreas, 40, 256-270, https://doi.org/10.1111/j.15023885.2010.00178.x, 2011.

McCarroll, D.: Potential and limitations of the Schmidt Hammer for relative-age dating: field tests on Neoglacial moraines, Jotunheimen, Southern Norway, Arct. Alp. Res., 21, 268-275, https://doi.org/10.2307/1551565, 1989.

Merisio, L.: Via Sett. Via Spluga, Lyasis Edizioni, Sondrio, Italia, 152 pp., 2014.

Mortara, G., Orombelli, G., Pelfini, M., and Tellini, C.: Suoli e suoli sepolti olocenici per la datazione di eventi geomorfologici in ambiente alpino: alcuni esempi tratti da indagini preliminari in Val d'Aosta, It. J. Quatern. Sci., 5, 135-146, 1992.

NGRIP-Members: High resolution record of Northern Hemisphere climate extending into the last interglacial period, Nature, 431, 147-151, https://doi.org/10.1038/nature02805, 2004a.

NGRIP-Members: North Greenland Ice Core Project Oxygen Isotope Data, IGBP PAGES/World Data Center for Paleoclimatology Data Contribution Series n. 2004-059, NOAA/NGDC Paleoclimatology Program, Boulder, Colorado, 2004b.

Oeschger, H., Riesen, T., and Lerman, J. C.: Bern radiocarbon dates VII, Radiocarbon, 12, 358-384, https://doi.org/10.1017/S0033822200008146, 1970.

Patterson, W. P., Dietrich, K. A., Holmden, C., and Andrews, J. T.: Two Millennia of North Atlantic seasonality and implications for Norse colonies, P. Natl. Acad. Sci. USA, 107, 5306-5310, https://doi.org/10.1073/pnas.0902522107, 2010.

Pellegrini, M.: Materiali per una storia del clima nelle Alpi Lombarde durante gli ultimi cinque secoli, Arch. Stor. Ticin., 55-56, 133-278, 1973.

Scapozza, C.: Stratigraphie, morphodynamique, paléoenvironnements des terrains sédimentaires meubles à forte déclivité du domaine périglaciaire alpin, Géovisions, 40, Université de Lausanne, Lausanne, Suisse, 551 pp., 2013.

Scapozza, C.: Appunti climatici e glaciologici sulle descrizioni della Valle di Blenio tra Settecento e Ottocento, Arch. Stor. Ticin., 155, 38-63, 2014.

Scapozza, C.: Evolution des glaciers et du pergélisol depuis le dernier maximum glaciaire dans la région du mont GeléMont Fort (Alpes Valaisannes, Suisse) : chronologie, modalités de la dernière déglaciation et datations des âges d'exposition à l'aide du marteau de Schmidt, Quaternaire, 26, 141-173, https://doi.org/10.4000/quaternaire.7250, 2015.

Scapozza, C.: Evidence of paraglacial and paraperiglacial crisis in Alpine sediment transfer since the Last Glaciation (Ticino, Switzerland), Quaternaire, 27, 139-154, https://doi.org/10.4000/quaternaire.7805, 2016.

Scapozza, C.: Pater Placidus a Spescha (1752-1833), Précurseur de la glaciologie au début du XIXe siècle dans les Alpes de l'Adula, Ann. Valais., 2019, 249-259, 2019a.
Scapozza, C.: Esempi di corrispondenze della suddivisione formale della Serie/Epoca dell'Olocene nella Svizzera italiana, Boll. Soc. Ticin. Sci. Nat., 107, 83-88, 2019b.

Scapozza, C. and Ambrosi, C.: Between glaciers, rivers and lakes: the geomorphological landscapes of Ticino, in: Landscapes and Landforms of Switzerland, edited by: Reynard, E., Springer Nature, Cham, Switzerland, 325-336, https://doi.org/10.1007/9783-030-43203-4_22, 2021.

Scapozza, C. and Scapozza, G.: Il modello regionale della linea di equilibrio dei ghiacciai per lo stadio di riferimento 1850 nelle Alpi Ticinesi Orientali (Svizzera), Geol. Insubr., 11, 35-44, 2015.

Scapozza, C., Lambiel, C., Reynard, E., Fallot, J.-M., Antognini, M., and Schoeneich, P.: Radiocarbon dating of fossil wood remains buried by the Piancabella rock glacier, Blenio Valley (Ticino, southern Swiss Alps): Implications for rock glacier, treeline and climate history, Permafrost Periglac., 21, 90-96, https://doi.org/10.1002/ppp.673, 2010.

Scapozza, C., Castelletti, C., Soma, L., Dall'Agnolo, S., and Ambrosi, C.: Timing of LGM and deglaciation in the Southern Swiss Alps, Géomorphologie, 20, 307-322, https://doi.org/10.4000/geomorphologie.10753, 2014a.

Scapozza, C., Lambiel, C., Bozzini, C., Mari, S., and Conedera, M.: Assessing the rock glacier kinematics on three different timescales: a case study from the southern Swiss Alps, Earth Surf. Proc. Land., 39, 2056-2069, https://doi.org/10.1002/esp.3599, 2014b.

Schmidt, E.: Der Beton-Prüfhammer - Ein Gerät zur Bestimmung der Qualität des Betons im Bauwerk, Schweiz. Bauzeit., 68, 378379, 1950.

Scotti, R., Brardinoni, F., Crosta, G. B., Cola, G., and Mair, V.: Time constraints for post-LGM landscape response to deglaciation in Val Viola, Central Italian Alps, Quaternary Sci. Rev., 177, 10-33, https://doi.org/10.1016/j.quascirev.2017.10.011, 2017.

Shakesby, R. A., Matthews, J. A., and Owen, G.: The Schmidt hammer as a relative-age dating tool and its potential for calibrated-age dating in Holocene glaciated environments, Quaternary Sci. Rev., 25, 2846-2867, https://doi.org/10.1016/j.quascirev.2006.07.011, 2006.

Shakesby, R. A., Matthews, J. A., Karlén, W., and Los, S. O.: The Schmidt hammer as a Holocene calibrated-age dating technique: Testing the form of the $R$-value-age relationship and defining the predicted-age error, Holocene, 21, 615-628, https://doi.org/10.1177/0959683610391322, 2011.

Simonett, J.: Splügenpass, Historisches Lexikon der Schweiz (HLS), available at: https://hls-dhs-dss.ch/de/articles/ 008823/2013-01-10/ (last access: 9 November 2021), 2013.

Steinemann, O., Reitner, J. M., Ivy-Ochs, S., and Christl, M.: Tracking rockglacier evolution in the Eastern Alps from the Lateglacial to the early Holocene, Quaternary Sci. Rev., 214, 106424, https://doi.org/10.1016/j.quascirev.2020.106424, 2020.

swisstopo: 1255 Splügenpass, Geological Vector Datasets GeoCover, $1: 25000$, Federal Office of Topography swisstopo, Bern, Switzerland, 2020.

Tinner, W., Lotter, A. F., Ammann, B., Conedera, M., Hubschmid, P., van Leeuwen, J. F., and Wehrli, M.: Climatic change and contemporaneous land-use phases north and south of the Alps 2300 BCE to 800 CE, Quaternary Sci. Rev., 22, 1447-1460, https://doi.org/10.1016/S0277-3791(03)00083-0, 2003. 
Walker, M., Berkelhammer, M., Björck, S., Cwynar, L. C., Fisher, D. A., Long, A. J., Lowe, J. J., Newnham, R. M., Rasmussen, S. O., and Weiss, H.: Formal subdivision of the Holocene Series/Epoch: a Discussion Paper by a Working Group of INTIMATE (Integration of ice-core, marine and terrestrial records) and the Subcommission on Quaternary Stratigraphy (International Commission on Stratigraphy), J. Quaternary Sci., 27, 549659, https://doi.org/10.1002/jqs.2565, 2012.

Winkler, S.: The Little Ice Age maximum in the Southern Alps, New Zealand: preliminary results at Mueller Glacier, Holocene, 10, 643-647, https://doi.org/10.1191/095968300666087656, 2000.
Winkler, S. and Lambiel, C.: Age constraints of rock glaciers in the Southern Alps/New Zealand - Exploring their palaeoclimatic potential, Holocene, 28, 778-790, https://doi.org/10.1177/0959683618756802, 2018.

Zoller, H. and Kleiber, H.: Vegetationsgeschichtliche Untersuchungen in der montanen und subalpinen Stufe der Tessinertäler, Ver Natur. Gesell. Basel, 81, 91-153, 1971.

Zumbühl, H. J. and Holzhauser, H.: Glaciers des Alpes du Petit âge glaciaire, Les Alpes, 3, 1-322, 1988. 